\title{
La aristocracia ibérica ante la romanización. Ideología y espacios funerarios en Marroquíes Bajos (Jaén)
}

\section{Iberian aristocracy in the face of romanization. Ideology and burial grounds in Marroquíes Bajos (Jaén)}

\author{
José Luis Serrano Peña \\ GIPAG (Grupo de Investigación del Patrimonio Arqueológico de Jaén) \\ Manuel Molinos Molinos \\ Centro Andaluz de Arqueología Ibérica
}

\section{RESUMEN}

Presentamos el estudio de las necrópolis de un asentamiento periurbano de la ciudad romana de Aurgi (Jaén), en el que, a través del estudio formal e ideológico de los espacios funerarios, planteamos una situación concreta de perduración de las tradiciones ibéricas en el contexto de la romanización en el Alto Guadalquivir.

\section{SUMMARY}

We present the study of the necropolis of a suburban settlement of the Roman city of Aurgi (Jaén). Through the formal and ideological study of these burial grounds, we present a particular situation of endurance of Iberian traditions in the context of Romanization in the Upper Guadalquivir.

PALABRAS CLAVE: Romanización, ritual funerario, aristocracia, Alto Guadalquivir.

KEYWORDS: Romanisation, funeral ritual, aristocracy, High Guadalquivir.

\section{INTRODUCCIÓN}

Marroquíes Bajos es un sitio arqueológico de la periferia septentrional de la ciudad de Jaén, un espacio que a partir de los años noventa del pasado siglo, como consecuencia del desarrollo del PGOU del municipio, se abrió al crecimiento urbano (Fig.1). Se trataba previamente de una zona de huerta, situada al norte de la antigua estación de ferrocarril, donde la actividad antrópica mas notable había sido la agricultura tradicional de regadío, favorecida por la es- pecial configuración topográfica de la ciudad que convertía esta zona en un espacio fácilmente irrigable. La alta capacidad de sus acuíferos ha hecho que históricamente multitud de arroyos cruzaran la ciudad de Jaén en dirección al valle del río Guadalbullón, la principal artería hídrica de la zona, donde Marroquíes Bajos queda en el centro. La configuración del núcleo urbano en la ladera del Cerro de Santa Catalina es indisociable de este perfil geológico y topográfico.

Con motivo de la expansión urbana, una vez aparecidos los primeros restos arqueológicos, y evidenciada su magnitud, la zona fue inscrita con carácter específico en el Catálogo General del Patrimonio Histórico Andaluz, como Zona Arqueológica (Orden de 22 de octubre de 2003. BOJA 227 de 25/11/2003), figura de protección que ha permitido una de las mas extensivas excavaciones arqueológicas conocidas en nuestro entorno. Cuatro grandes fases, calcolítica, ibérica, romana y medieval islámica se definen en un área de más de 1,5 millones de metros cuadrados, la única zona de posible expansión urbana moderna dada la accidentada orografía sobre la que se emplaza la ciudad. Las instrucciones particulares de la Zona Arqueológica de Marroquíes Bajos (en adelante ZAMB) han propiciado un exitoso, no exento de polémica y a veces de franca confrontación, modelo de gestión del patrimonio arqueológico y han avalado no sólo la excavación de miles de estructuras, sino también la posibilidad de integrar la información contextual de los propios espacios agrarios de las 


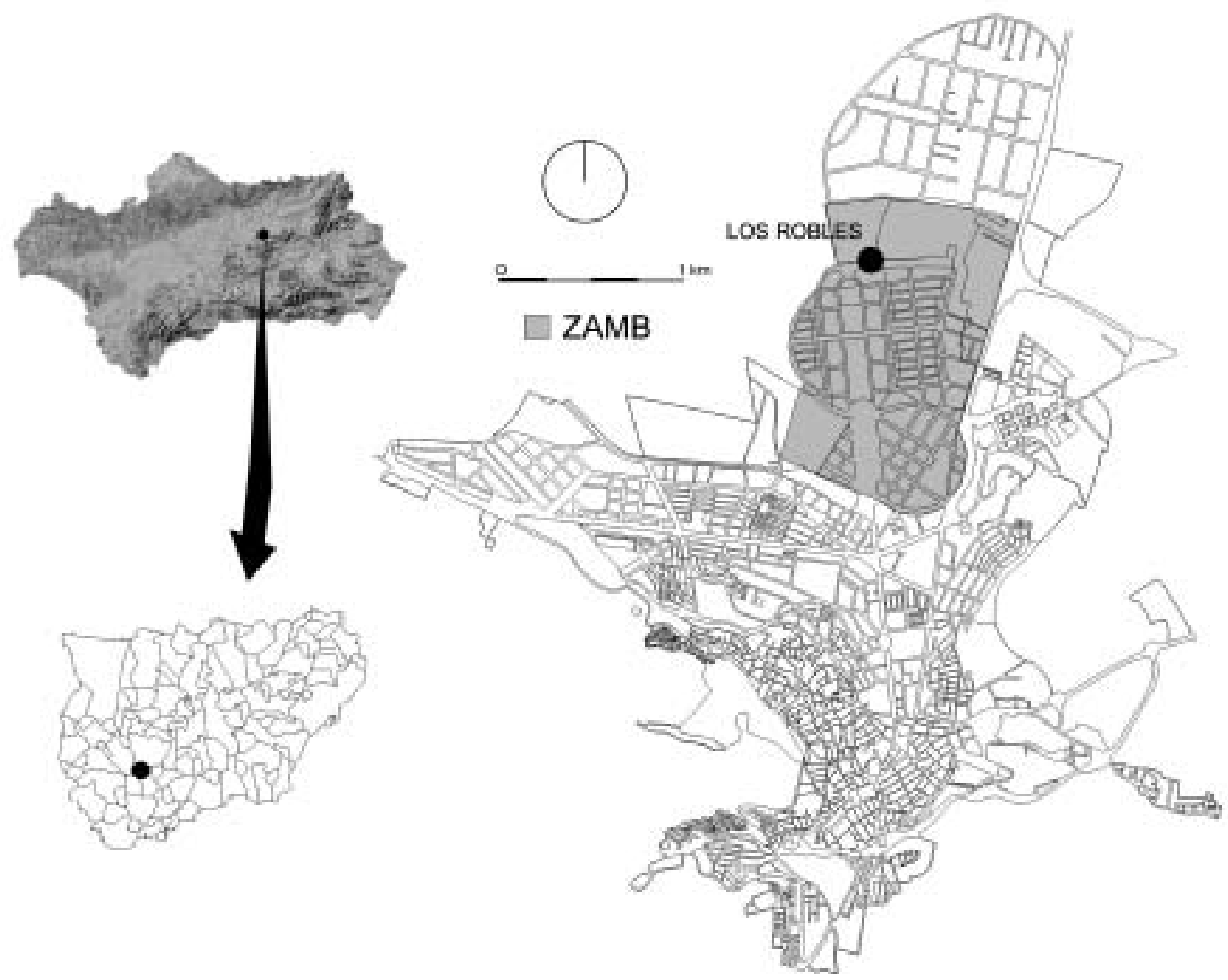

Figura 1. Situación de Jaén.

diferentes fases documentadas. Canales de agua, balsas, huertas, chozas, campos de silos, cultivos de vides y de otros productos agrarios, etc., permiten hoy valorar extensivamente el desarrollo de la ciudad desde la Prehistoria Reciente, tanto en la perspectiva urbana como en la agraria. Como indican los arqueólogos que desde la Consejería de Cultura han administrado buena parte de los trabajos en la ZAMB, «no estamos trabajando en un 'yacimiento' al uso, sino que estamos levantando por capas un paisaje que ha sido esculpido a lo largo de casi 5000 años» (Zafra et alii 1999).

Resultados parciales de los trabajos de investigación arqueológica, en los diferentes momentos que definen la secuencia del enorme asentamiento, ya han sido publicados en distintos soportes y la ZAMB es ya bastante conocida en algunas de sus fases más relevantes, en particular las prehistóricas. Sin embargo, los resultados de los trabajos desarrollados en amplias zonas de nueva urbanización que han obte- nido secuencias ibéricas y romanas apenas han visto la luz en revistas especializadas, aunque sí publicitadas en diversos foros y reuniones científicas o de difusión ${ }^{1}$. No es nuestra intención desarrollar aquí esas primeras conclusiones generales, que por otro lado están siendo tratadas en un proyecto general de investigación ${ }^{2}$, pero para enmarcar el objetivo de este trabajo y poder entender las propuestas que a continuación presentamos sobre una zona funeraria muy

\footnotetext{
${ }^{1}$ Comunicaciones en: I Jornadas Cordobesas de Arqueología Andaluza, Córdoba, 2000; Expoliva 2005: Foro de la Cultura del Aceite de Oliva. I Congreso de Jardines y Campos de cultivo, Barcelona, 2007; XII Jornadas Iberas: La riqueza arqueológica del municipio de Jaén, Jaén, 2008.

${ }_{2}$ Este trabajo y la tesis en curso que desarrolla las fases ibérica y romana en Marroquíes Bajos se están llevando a cabo en el marco del Proyecto I+D+I «Iberos y Romanos en Jaén» (PBHA 2002-00482. Ministerio de Ciencia y Tecnología), dirigido por Manuel Molinos, y forma parte de una tesis doctoral dirigida desde el Centro Andaluz de Arqueología Ibérica (José Luis Serrano Peña), actualmente en fase de redacción.
} 


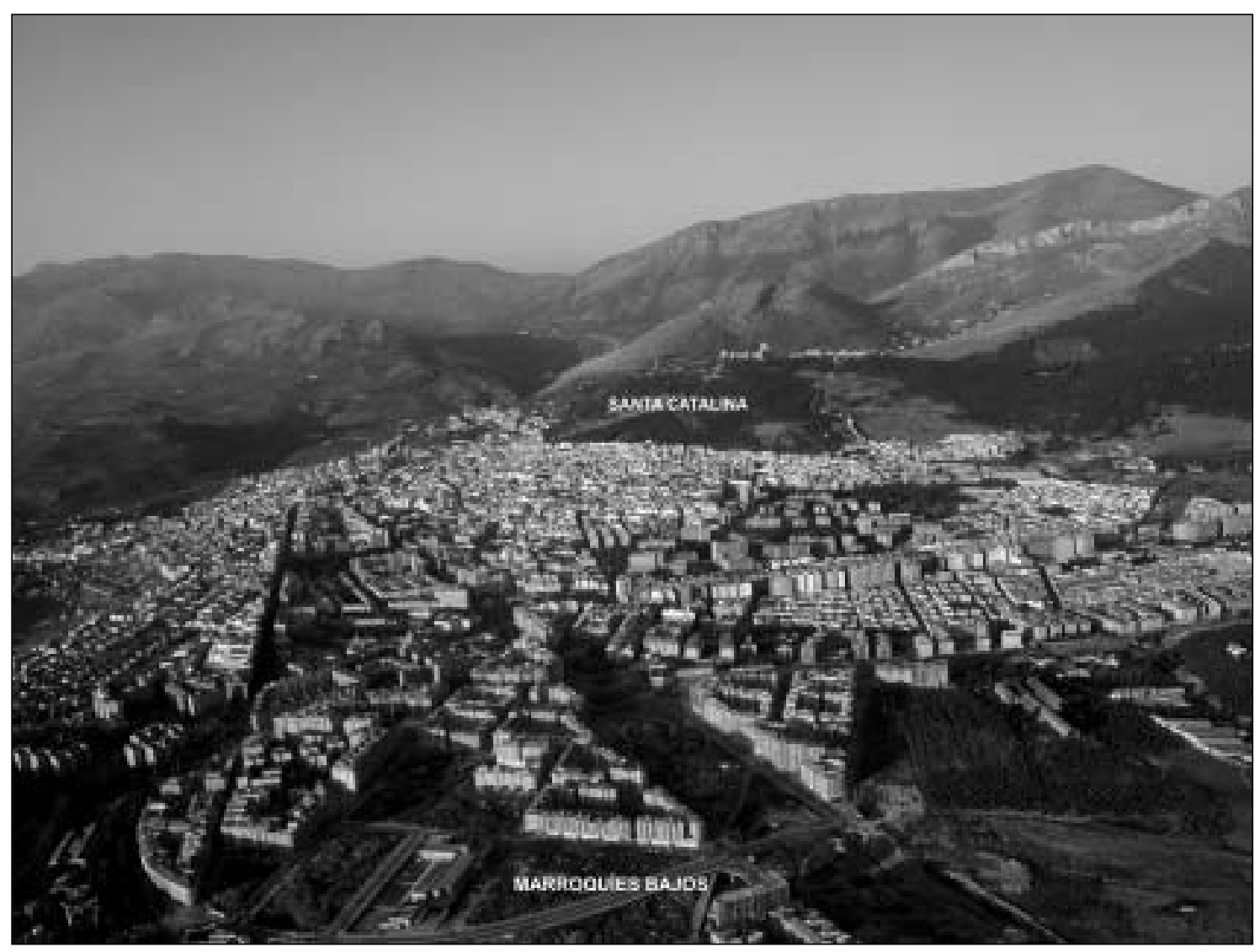

Figura 2. Vista aérea de Jaén.

específica del complejo asentamiento cortijo Los Robles, es necesario ofrecer una visión de lo que suponen las fases iberorromana y romana en la ZAMB.

Los cientos de intervenciones arqueológicas, desarrolladas bajo la fórmula de excavaciones de urgencia o preventivas, implicaban financiación privada y múltiples equipos de investigación, con lo que se ha conseguido documentar amplias superficies, imposibles de abordar desde proyectos de investigación tradicionales, definir multitud de fases y particularizar dentro de ellas procesos de desarrollo lento y hacerlo de forma extensiva, lo que es inusual en arqueología. En contra, el enorme volumen de documentación y de materiales arqueológicos generado tiene como lastre la diversidad de criterios con que se han abordado los trabajos de campo y, por descontado, las conclusiones a las que han llegado los investigadores. Los estudios de materiales cerámicos son prácticamente inexistentes, salvo aquellos que se han asumido desde propuestas puntuales (tesis, tesinas y algún estudio particularizado) o en nuestro caso desde el proyecto «Iberos y Romanos en Jaén». La propuesta realizada por la administración cultural para unificar criterios generales y particulares, incluidos los metodológicos, en los informes técnicos en la ZAMB (Hornos et alii 2000), no siempre ha tenido el eco necesario entre los profesionales que allí han trabajado. Es por ello que la documentación generada en los últimos 15 años (1994-2009) constituye un complicado puzzle en el que con frecuencia es muy difícil distinguir nexos de unión y trazas de homogeneidad, sobre todo cuando se trata de establecer relaciones cronológicas en tiempo corto. Pero estas dificultades no pueden ser una excusa para no avanzar en la investigación, aunque frecuentemente se esgriman para evidenciar las debilidades del sistema (Lizcano et alii 2004) sin apreciar las ventajas que ofrecen la multiplicidad de enfoques y la disponibilidad económica.

Tras superar las zonas de mayor densidad arqueológica (fases prehistórica y medieval) en la mitad sur 
de la ZAMB, la más cercana al casco urbano de Jaén, la mayor parte de Marroquíes presenta una dispersión de restos arqueológicos, fundamentalmente ibéricos, romanos y medievales, que resultan difíciles de documentar aisladamente, en especial cuando los resultados proceden de actividades como los seguimientos de los movimientos de tierras con medios mecánicos, una de las formas de intervención contemplada en las Instrucciones Particulares. Por ello, tanto en «Iberos y Romanos en Jaén» como en este trabajo nos hemos centrado en aquellos proyectos que, por su envergadura y duración, presentan resultados generales de los que poder extraer conclusiones para las fases iberorromanas y romanas. Esta modalidad de intervención ha sido la más frecuentemente aplicada en buena parte de la ZAMB, especialmente en la zona central, donde se sitúa una pequeña elevación dominada por un caserío tradicional que se conoce como Cortijo Los Robles.

El estudio de la sociedad antigua puede plantearse desde varios puntos de vista, pero no cabe duda de que el mundo funerario nos ofrece una magnífica oportunidad de análisis, por cuanto que sintetiza determinados comportamientos sociales y prácticas públicas y privadas. Desde el año 1995 se han excavado varias necrópolis en la ZAMB, algunas de las cuales están claramente vinculadas al asentamiento de Los Robles. Estas necrópolis crean un cinturón alrededor de este, pero, dada la secuencia estratigráfica y su tipología, parece claro que no son coetáneas y que abarcan un amplio periodo entre los siglos i y VIII. Algunas de estas necrópolis enlazan incluso con el mundo tardovisigodo o emiral de primera época (Serrano y Castillo 2000; Salvatierra et alii 2001).

La información disponible (publicada o en informes técnicos consultados) sólo permite elaborar un plano detallado del entorno del asentamiento Los Robles, mientras que específicamente del propio sitio conocemos datos parciales (Serrano y Cano 2003; López et alii 2007). En realidad, las Instrucciones Particulares de la ZAMB han permitido excavar grandes superficies de terreno en las que no había evidencias arqueológicas en forma de hábitat, pero sí información muy relevante de otros tipos de construcciones, lo que ha provocado una situación paradójica: sabemos más de un gran asentamiento romano por su hinterland periférico que por su propia estructura interna. La investigación del entorno del sitio se ha hecho con motivo de la urbanización de esa zona de Jaén, habiéndose intervenido sobre viales, parcelas para la edificación de viviendas y zonas verdes. Por otro lado, cabe esperarse que un sitio ocupado durante un periodo de tiempo tan prolongado (al menos en un segundo periodo desde el siglo III a.n.e. hasta el siglo viII d.n.e.) tenga una superposición de fases constructivas que no siempre clarifica la lectura histórica. Por el contrario, el territorio ofrece unas perspectivas de análisis espacial, sincrónica y diacrónica, que puede darnos una visión rica y novedosa del proceso de romanización, del Alto Guadalquivir en general y de la ciudad de Aurgi en particular. También del propio concepto de romanización.

En el año 2002 se llevó a cabo una intervención para delimitar el extremo sur del asentamiento de Los Robles y obtener una secuencia estratigráfica completa de una amplia superficie de terreno junto al arroyo El Molinillo, pero sobre todo nos permitió excavar una de las principales necrópolis vinculadas a este sitio $^{3}$ (Necrópolis 1) y delimitar el extremo sur del asentamiento romano. La parcela JN-4 se encuentra en el extremo norte de la urbanización, al pie de una pequeña elevación que domina el cortijo Los Robles. Toda la parcela constituye una ladera suave inclinada al sureste, en cuyo lado sur circula el arroyo El Molinillo y por el lado este el de la Magdalena. Ambos convergen a unos 150 metros al nordeste del asentamiento. Existía abundante documentación más al sur de Los Robles, donde se ubicaba una extensa necrópolis romana y visigoda excavada entre los años 1999 y 2001.

En 2005 dieron comienzo las excavaciones previas a la construcción de una serie de infraestructuras urbanas promovidas por el Ayuntamiento de Jaén. Estas se centraron en un sector que limitaba por el norte con la Necrópolis 1 y que ya se adentraba en las zonas de habitación del complejo Los Robles. Los resultados de esta intervención, inéditos por el momen$\mathrm{to}^{4}$, fueron la localización de dos zonas bien diferenciadas dentro del complejo: una industrial con una prensa de aceite idéntica a la excavada en 1999 en el sector Cuétara (Serrano y Cano 1999; Serrano 2004b), es decir, con una batería de seis prensas de viga y contrapeso de grandes dimensiones, y una zona residencial, al nordeste de la necrópolis, donde la pars urbana reveló una piscina de claro contenido ritual por la aparición de varias esculturas dispuestas alrededor, de entre las que destaca un retrato femenino que sigue el modelo de los retratos de la emperatriz Domicia Longina (López y Baena 2007). Bajo ambos

\footnotetext{
3 Trabajo dirigido por José Luis Serrano y Juana Cano, (GEPARQ' 99 SL) para EPSA, Empresa Pública del Suelo de Andalucía.

${ }^{4}$ Agradecemos al arqueólogo director, Antonio López, permitirnos consultar la documentación del informe preliminar de esa intervención desarrollada para la Empresa Aqualia, sin la cual hubiera sido imposible este trabajo.
} 
sectores aparecían restos de edificaciones de época Julio-Claudia. La fase de máxima expansión del asentamiento se fija hacia mediados del siglo II d.n.e.

Esta intervención tuvo finalmente una ampliación mediante una excavación de urgencia dirigida por Marcelo Castro y promovida por la Delegación de Cultura de Jaén en el verano de 2006, con el objeto de documentar el extremo norte de este espacio ritual porticado alrededor de los balnea. Esta intervención descubrió nuevas esculturas y definió las fases de construcción del sector (Castro 2009).

La envergadura de los hallazgos está en consonancia con la entidad de las necrópolis estudiadas por este equipo, y en especial con la Necrópolis 1. Es por ello que haremos referencia a esas intervenciones a lo largo de este trabajo, porque, aunque sólo se ha documentado un escaso $20 \%$ de la superficie, la muestra es más que significativa de la entidad del sitio.

\section{EL CONTEXTO GENERAL}

El norte de Jaén, donde se encuentra Marroquíes Bajos, está dominado la cuenca fluvial del arroyo La Magdalena. Este nace en las cotas más altas de la actual ciudad de Jaén, con un importante volumen de caudal, recorre la parte central de la depresión a la que da nombre y desemboca en el río Guadalbullón, a unos $5 \mathrm{~km}$ de Jaén, frente al oppidum ibérico de Puente Tablas. Los aportes aluviales de este curso de agua y otros menores han acabado formando una cubeta sedimentaria, muy amplia por el sur $(3,5 \mathrm{~km}$ aprox.) y estrecha por el norte (2 km aprox.), con una longitud de unos $5 \mathrm{~km}$ entre el cerro Santa Catalina y el río Guadalbullón. Esta depresión, agrícolamente muy fértil, presenta frecuentemente lagunas naturales que casi permanentemente ocupan amplias superficies, cuyo topónimo ha llegado hasta nosotros como Las Lagunillas. Otros arroyos menores de agua dulce (El Molinillo y Arroyo A) confluyen en el de La Magdalena, creando una pequeña cuenca hidrográfica de enorme valor estratégico y económico.

El centro de esta cuenca está presidido por el cortijo Los Robles, una pequeña elevación de unas 2,5 hectáreas, donde se levantaba el antiguo cortijo que le da nombre, más relevante respecto al entorno en la Antigüedad que hoy día, un lugar topográficamente estratégico en el que se han desarrollado sucesivos asentamientos, en la actualidad enmascarado por la propia acumulación de sedimentos (Fig. 3).

Desde el comienzo de los trabajos arqueológicos en la ZAMB, en 1995, se puso de manifiesto la existencia de niveles de ocupación de esta zona al norte de Jaén desde el siglo II a.n.e., quizás algo antes, de forma continuada hasta el final del mundo antiguo (Serrano 1997 y 2004a; Zafra 1997). Conforme han ido desarrollándose trabajos arqueológicos, esta primera percepción ha quedado definitivamente confirmada y hoy parece claro que el origen de esta ocupación responde a nuevas estrategias de explotación del territorio sólo comprensibles en el contexto de la conquista romana, ya que se advierte un vacío entre una primera ocupación ibérica durante los siglos VI$\mathrm{v}$ a.n.e. (ZAMB 6) y el inicio del siglo II a.n.e. (ZAMB 7). Sobre la primera ocupación ibérica, en los últimos años nuevas aportaciones permiten dibujar



Figura 3. Planteamiento intervención en Necrópolis 1. 
un panorama que creemos esclarecedor. Así, en 2005, se documentaron en el extremo norte de la ZAMB sistemas de conducción y almacenaje de aguas para regadío cuyos materiales se fechan en el siglo VI-V a.n.e., en las proximidades de la elevación del cortijo Los Robles (Serrano et alii 2005). A ello hay que sumar en 2006 la aparición de nuevas estructuras, con similar función y cronología, bajo el actual casco urbano de Jaén (Portero et alii 2007). Este conjunto de estructuras han sido propuestas como parte de un modelo aristocrático de explotación del territorio que se basa en la intensificación de la producción agraria, mediante un masivo desarrollo de las tecnologías asociadas al aprovechamiento del agua, frente al modelo extensivo cerealista que domina aparentemente la Campiña a partir del siglo v a.n.e. (Ruiz et alii 2007; Ruiz y Molinos 2008). En esta concepción de la ocupación, generada desde el oppidum de Santa Catalina (en la actual ciudad de Jaén), no es extraño encontrar formas de ocupación habitacional de tipo campesino, como chozas hortelanas (Serrano et alii 2001) o incluso espacios vinculados a los estamentos aristocráticos, como el que pensamos debe localizarse en el propio cerro Los Robles, en la misma ZAMB.

Sea como fuere, los dos modelos de explotación del territorio parecen haber generado un conflicto entre los oppida de Santa Catalina y Puente Tablas que se saldó con la victoria del modelo aristocrático y nuclearizado que representa este último (Ruiz y Molinos 2008), lo que significó un largo periodo de inactividad en Marroquíes, al menos no con la intensidad de los momentos anteriores a la mitad del siglo v a.n.e. y los posteriores al siglo III a.n.e. En lo que a nosotros nos interesa aquí, podemos comprobar que el antecedente más claro y directo de la ocupación de la depresión de La Magdalena en época iberorromana se encuentra precisamente en este modelo abortado de explotación territorial en el periodo Ibérico Antiguo (siglos vI-v a.n.e.). La reocupación del campo a partir de los inicios del siglo II a.n.e. coincidiendo en la misma zona no es casual. Los sistemas de regadío y las construcciones hidráulicas se superponen en algunos puntos sobre las del periodo Ibérico Antiguo con una exactitud que viene derivada de la configuración topográfica del entorno. El hecho de que la estructura hídrica del valle no hubiese variado en esos siglos de abandono y la persistencia del sistema de espacios inundables, está en la base de esa mimética ocupación de los mismos espacios en dos fases diferenciadas, entre las que no hay posibilidad de relación en términos históricos.
En cualquier caso, parece demostrado que desde el inicio de la conquista romana, a partir del abandono definitivo de la Plaza de Armas de Puente Tablas a finales del siglo III a.n.e., se reconstruye la huerta vinculada a Santa Catalina, en paralelo con una nueva concentración de población en las terrazas bajas del cerro, bajo el casco antiguo de Jaén. Este núcleo será el germen del municipio romano de Aurgi (Serrano 2004a).

La construcción de la huerta, entendida como sistema de explotación del territorio que implica formas de trabajo cooperativas para la creación de las infraestructuras necesarias para el trasvase de aguas, canalizaciones, puntos de almacenaje, división de campos e incluso hábitat directo en el campo, un modelo que estructuralmente es muy diferente al del secano, se debió realizar a partir de proyectos de partición del territorio entre grupos aristocráticos que, en la nueva coyuntura de la conquista romana, adoptan estrategias dirigidas al control de los medios de producción, léase la tierra, y la fuerza de trabajo, el campesinado. En cualquier caso, no reconocemos formas de división y asignación de la tierra donde el campesinado urbano fuera el beneficiario de este tipo de políticas. Más allá de la depresión de La Magdalena no existe este fenómeno de ocupación campesina/aristocrática, estando el territorio circundante aurgitano ocupado sólo por torres diseminadas en los confines de su territorio.

La distribución de materiales de superficie aportado por las prospecciones y las excavaciones bajo el casco urbano, y más al norte, en Marroquíes Bajos, demuestran que la huerta iberorromana ocupa una vasta superficie junto a los principales arroyos que configuran la depresión de La Magdalena. Precisamente, la excavación de infraestructuras de regadío (canalizaciones y balsas), junto a la distribución de campos de silos y estructuras de hábitat es lo que sugiere la división del territorio vinculado a Aurgi en pagos aristocráticos. En el caso de Marroquíes Bajos creemos detectar dos de ellos, donde los cursos de agua dulce permanentes marcan los límites territoriales: Cerro de la Virgen Blanca y Los Robles. De ellos nos interesa particularmente este último (Fig.4).

Sobre el cerro de Los Robles, que preside la zona más centro-oriental de la depresión, apenas se han realizado trabajos arqueológicos que permitan definir estratigráfica y espacialmente el origen del asentamiento. Hasta el momento sólo se han llevado a cabo investigaciones en sus laderas e inmediaciones, detectándose secuencias que apuntan una continuidad del hábitat desde el Bronce Final. De cualquier forma, la superposición de un enorme establecimiento 


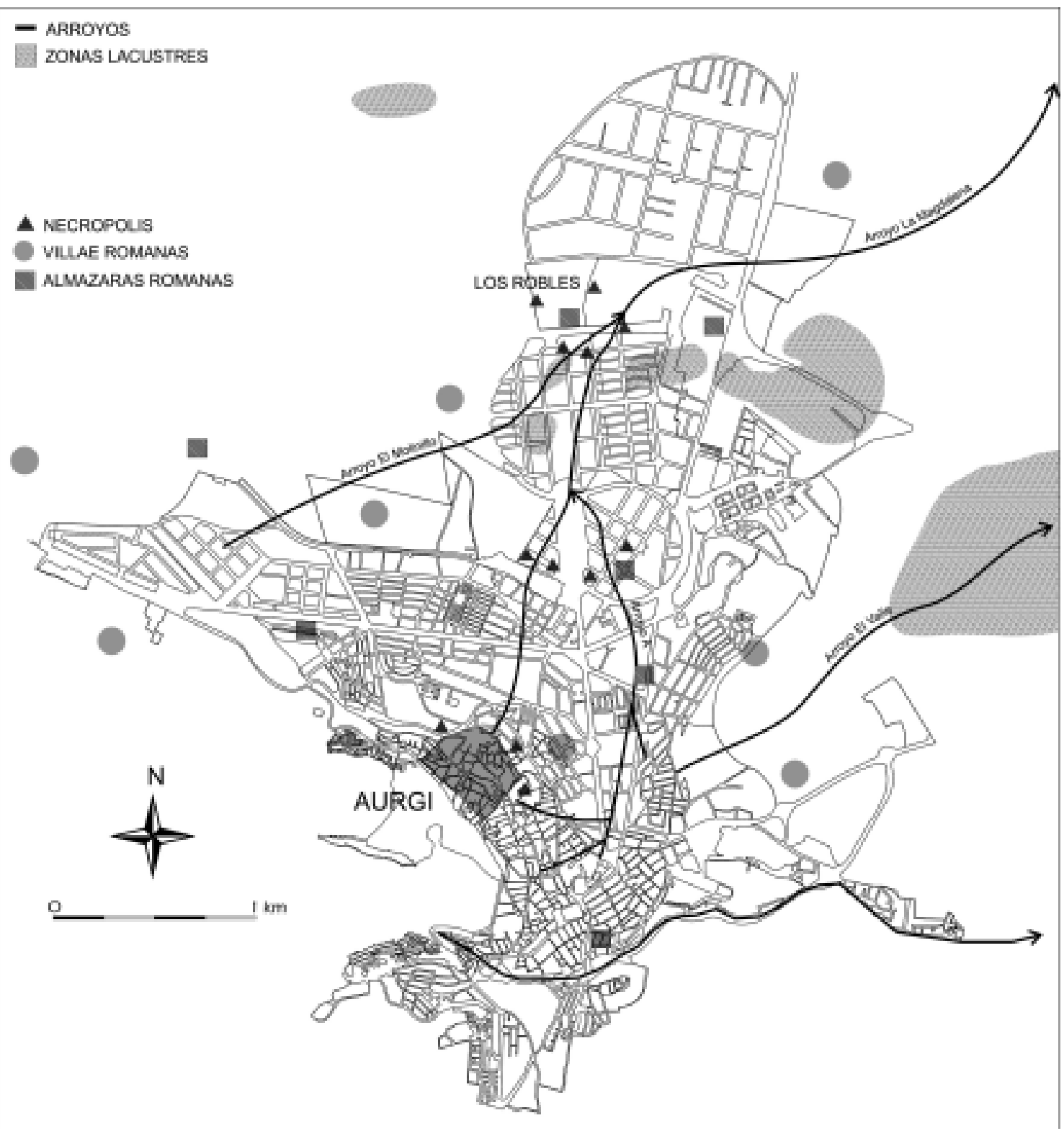

Figura 4. Jaén romano.

romano imperial, que incluye una impresionante almazara para la producción industrial de aceite de oliva (López et alii 2007), parece haber arrasado buena parte de la secuencia previa, por lo que de momento sólo contamos con datos aislados, a la espera de que la excavación del núcleo desvele la secuencia completa.

Los Robles dominan un punto importante del valle del arroyo de la Magdalena porque, como se ha indicado, se sitúa precisamente en la confluencia de dos de los principales arroyos que lo recorren: El Molinillo y La Magdalena. Los sistemas de regadío confluyen también en ese punto, de forma que podemos afirmar con seguridad que el asentamiento controla, a partir del inicio del siglo II a.n.e. y hasta el final del I d.n.e., desde su posición estratégica, los campos irrigados, los campos de silos y el disperso hábitat campesino vinculado.

En la secuencia aportada por la excavación de un vial y colector al pie del cerro por el sur (López et 
alii 2007), se aprecian materiales cerámicos de finales del siglo III y II a.n.e.; esta secuencia se confirma en la obtenida en los sondeos de la zona verde JN4 (Serrano y Cano 2003). Así, podemos concluir que Los Robles tienen ocupación al menos desde principios del siglo II a.n.e. y durante el i a.n.e., lo que además corrobora la localización de dos monedas de la ceca de Castulo, una de la tercera emisión ${ }^{5}$ y otra de la quinta ${ }^{6}$. En cualquier caso no puede considerarse un establecimiento rural campesino, dada la complejidad de los restos constructivos en los alrededores del cerro. Este sistema de explotación del territorio perdura hasta finales del siglo i a.n.e., momento en el que documentamos el abandono de los sistemas de irrigación y la destrucción de las estructuras de hábitat (Serrano 2004b). Hemos propuesto que las circunstancias que condujeron a esta situación fueron la implantación de los cultivos de secano, y por ende, la transformación de la aristocracia ibérica en una clase propietaria interesada desde ese momento por nuevas formas de apropiación y enriquecimiento, que tiene más que ver con las clases propietarias romanas que con la aristocracia tradicional ibérica. El negocio generado por la afluencia de productos a Roma y el limes a partir de Augusto, regulado o no por impuestos como la Annona, fue suficiente estímulo para los provinciales con capacidad de inversión en la tierra, es decir, para los aristócratas iberos propietarios de los medios de producción. En este contexto, la fuerza de trabajo se resistió a desvincularse de una forma tradicional de explotaciones que aseguraba productos básicos, aunque no almacenables o exportables, salvo en ámbitos muy reducidos, como es la huerta. El mismo hecho del conflicto, recogido en la documentación arqueológica con niveles de destrucción violenta del hábitat, sugiere una vinculación a la tierra de un campesinado posicionado en un punto capaz de discutir los términos de la nueva orientación económica que se pretendía dar a la tierra de Aurgi, o lo que es lo mismo, una población no servil aunque ciertamente vinculada a la tierra.

El resultado del conflicto fue la implantación de la producción de olivar y cereal en aquella zona que

\footnotetext{
${ }^{5}$ Unidad: A/. Cabeza masculina diademada a derecha; cue1 lo vestido o adornado con collar. Gráfila de cuerda con trazos paralelos. R/ [ ] Gráfila de cuerda con trazos paralelos. (c.195-179 a.n.e. CNH,32,9, García-Bellido y Blázquez 2001: 228). El estudio de todo el material numismático referenciado en este artículo ha sido elaborado por M. ${ }^{\mathbf{a}}$ de los Santos Mozas.

${ }^{6}$ Unidad: A/. Cabeza masculina diademada a derecha; delante, símbolo mano. R/ Esfinge alada marchando a derecha tocada con casco; delante, estrella. [En exergo, leyenda ibérica, Kactilo] Gráfila de puntos. (c. 165-80 a.n.e. CNH, 35, 38, García-Bellido y Blázquez 2001: 231)
}

anteriormente se había caracterizado por el regadío, la desecación de las zonas pantanosas de Las Lagunillas y el abandono del hábitat campesino (ZAMB 8). A partir de ese momento se construyen las primeras almazaras en los alrededores del asentamiento de Aurgi: Cuétara (Serrano 2004b), Los Robles (López et alii 2007), calle Olid (Gámez y Moya 2001), El Corte Inglés (Portero et alii 2007) y otras. Una ingente producción de aceite que se dirige al mercado imperial y cuyos beneficios repercuten sobre la clase aristocrática indígena. No consideramos a esta como oligarquía municipal, no ya porque la deductio de Aurgi y la constitución del municipio latino no se producirán hasta época flavia y, por tanto, desconocemos el ordenamiento político de esta pequeña ciudad escasamente urbanizada, sino porque los atributos propios de esta clase dirigente indígena no han cambiado sustancialmente respecto de la centuria anterior, es decir, formas de relaciones clientelares más o menos sutiles basadas en la propiedad de la tierra. La constitución del municipio flavio tiene como consecuencia directa, como ya hemos expuesto en otros trabajos (Serrano 2004a), la construcción de una nueva muralla y la redefinición del espacio urbano, incluyendo la aparición de nuevas formas y técnicas edilicias. En paralelo con los cambios que reconocemos en la ciudad desde la arqueología, aparecerán los primeros sitios que pueden interpretarse como asentamientos campesinos de tipo itálico, $v i$ llae, ocupando el campo, hecho que sólo advertiremos desde finales del siglo i d.n.e. Antes de época flavia no conocemos la existencia de epigrafía honorífica y por tanto no tenemos pruebas de la existencia de cargos municipales vinculados al ordenamiento político de Aurgi, así como de la mayoría de los oppida del Alto Guadalquivir.

Así, antes de su deductio, hemos de suponer que Aurgi, como la mayoría de los asentamientos ibéricos de la campiña, siguieron siendo núcleos urbanos sin estatuto jurídico específico, comunidades estipendiarias que, sin otro estímulo por parte de Roma, mantuvieron su estructura política más o menos estable, al menos hasta época augustea, lo que no quiere decir que no sufriera la presión de nuevas formas sociales urbanas en transformación hacia la ciudadanía. En el caso de Aurgi sabemos, además, que el grado de urbanización, en lo que comúnmente se vienen considerando como parámetros romanos, era muy escaso, o al menos eso sugieren las intervenciones arqueológicas que han detectado esas fases (Serrano 2004). En realidad, en el territorio del Alto Guadalquivir la pervivencia de las formas urbanas iberas, incluida la tecnología de la construcción, es 
una constante que ha sido contrastada en numerosas intervenciones arqueológicas realizadas en los años 80-90 del pasado siglo: Atalayuelas de Fuerte del Rey (Castro et alii 1990), Gil de Olid (Crespo et alii 1987) o Cabeza Baja de Encina Hermosa (Hornos et alii 1987). Pero la prueba que demuestra la vigencia de los modelos indígenas es la colonización de la depresión Víboras-Guadajoz con núcleos urbanos que siguen reproduciendo el tipo del oppidum fortificado en altura (Montilla et alii 1989), siendo modelos estructurales y urbanísticos netamente ibéricos ${ }^{7}$. Esta extensa zona al sur del Subbético constituía un espacio sin ocupación ibérica permanente desde el siglo IV a.n.e.; desde principios del siglo II a.n.e. se coloniza como un proyecto lanzado bien desde Obulco (Porcuna) o quizás desde Tucci (Martos). Igual podemos decir del valle del Guadalquivir, donde ya Ponsich (1987) advirtió la existencia de nuevos asentamientos asociados a la presencia de vajilla campaniense jalonando el río y la vía de Aníbal. Hasta época augustea la cultura material es mayoritariamente tradicional. Así, en el hábitat ibérico en la depresión de La Magdalena el porcentaje de cerámica ibérica es del 99\%, incluyendo las ánforas, entre las que apenas reconocemos los tipos republicanos Dressel 1 o las grecoitálicas.

En consonancia con la continuidad en la cultura material y estructura urbana tradicional ibérica, podemos pensar que la estructura política indígena continuó siendo sustancialmente similar a la existente a la llegada de los romanos, es decir, un ordenamiento aristocrático nuclear, que en algunos territorios podía contemplar situaciones de dependencia entre núcleos urbanos. Al menos eso se puede extraer de la lectura de Livio (32.21) cuando describe la posición de Culchas durante los acontecimientos posteriores a la II Guerra Púnica. Estos pagos polinucleares, como el caso de Castulo (Ruiz 2009) quedarán limitados en su capacidad de actuación en el territorio por la intervención romana, pero no desaparecen. También puede interpretarse como continuidad del mundo ibérico la multiplicidad de cecas ibéricas que circulan por el Alto Guadalquivir durante los siglos II y I a.n.e. Pero, sobre todo, por los acontecimientos relatados en las fuentes. El decreto de L. Emilio Paulo (CIL II 5041) de 189 a.n.e. demuestra la autoridad de Roma para resolver problemas de dependencia entre comunidades indígenas. Pero la autoridad y la incorporación del territorio provincial a

\footnotetext{
${ }^{7}$ Extremo ampliamente confirmado por la tesis doctora que en estos momentos está redactando en su fase final Laura Wiña, becaria del Centro Andaluz de Arqueología Ibérica.
}

Roma recogidos en los términos de los pactos (deditio in fidem) implican que las comunidades indígenas conservarán su núcleo urbano, su ordenamiento social y su organización económica tradicional (González Román 1999). En este contexto, a lo largo de los siglos II y i a.n.e., la continuidad de la realidad prerromana es la tónica en el Alto Guadalquivir. Y dentro de esta la estructura política, que no parece presentar cambios significativos hasta época del Principado.

La pervivencia de las formas culturales ibéricas es aún apreciable después de Augusto, en las estructuras del hábitat y en muchos otros aspectos de la cultura material, la cerámica por ejemplo. En recientes intervenciones en Porcuna (Molinos y Fernández 2006) hemos podido constatar como, en un momento de la segunda mitad del siglo I d.n.e., el porcentaje de materiales cerámicos de indudable tipología ibérica o perduraciones de ésta, supera el $70 \%$ del total documentado. Sin embargo, advertimos que la arquitectura específicamente relacionada con la industria del aceite que se desarrolla a partir del siglo I d.n.e., denota unas características claramente romanas en el uso generalizado de la tégula, en la mampostería regular, uso de arco de medio punto, revestimientos parietales, opus caementicium, etc., apareciendo ya la primera sigillata itálica, gálica y tipo Peñaflor, además de cerámica doméstica ya claramente romana. Aunque la demanda de cerámica ibérica seguirá siendo muy importante, como demuestra el hecho de que, hasta el final de época julio-claudia, la producción de ésta en los alfares de Los Villares de Andújar es masiva (Choclán, 1984).

Así, durante el periodo augusteo y julio-claudio asistimos a las primeras evidencias de transformación económica que no pueden explicarse sin la existencia de nuevas formas sociales urbanas, toda vez que el territorio se encuentra casi despoblado. La demanda de productos de uso doméstico de cierto valor, como la vajilla de mesa sigillata, el vidrio, las lámparas a molde y toda una panoplia de productos orientados a un mercado de cierto poder adquisitivo, que desde ahora aparecen abundantemente en el registro arqueológico, sólo puede entenderse como manifestaciones de nuevos grupos sociales urbanos. Las fuentes de riqueza que abre el mercado del abastecimiento imperial de Roma y provincias generaron inmensas fortunas, pero también facilitaron una distribución más amplia de la riqueza. No tenemos evidencias de que el excedente de esta nueva situación se dirigiera al evergetismo, urbanización u otras expresiones públicas de poder. No al menos en la campiña del Alto Guadalquivir. Para nosotros, la razón es que 
simplemente no era necesario si se mantenía el escenario político creado tras la II Guerra Púnica. Es decir, un ordenamiento político tradicional ibérico, aunque probablemente evolucionado hacia escuetas magistraturas urbanas. La imagen proyectada por las fundaciones coloniales augusteas en el territorio, aunque sólo se realizaron dos, la Colonia Augusta Gemella Tucci y la Colonia Salaria, así como la concesión de privilegios a otras (posiblemente Urgavo, Isturgi e Iliturgi) debió ser un acontecimiento de gran impacto social y territorial, y su influjo en el proyecto de estabilización del Principado creó un marco para futuras aspiraciones de las emergentes clases urbanas. En ese ambiente económico y social, el poder en los núcleos urbanos seguía en manos de quien detentaba el control de la tierra. No tenemos motivos para pensar que, quien ordenó la eliminación de la huerta tradicional en Marroquíes Bajos a fines del siglo I a.n.e., no fuese quien dirigió la plantación de olivos y la construcción de los complejos oleícolas que aparecen allí. Por eso, lo definimos como aristocracia de origen ibérico, y aunque entendemos que no es exactamente la misma forma de ejercicio del poder del siglo II a.n.e., es una definición más apropiada que oligarquía urbana, más propia del fenómeno municipal.

En resumidas cuentas, pensamos que durante el siglo I d.n.e. la aristocracia indígena se encontraba inmersa, efectivamente, en un proceso de romanización favorecido por las consecuencias políticas de la época de Augusto, pero sobre todo por la nueva coyuntura económica que potenciaba la monetarización de la provincia y alentaba la atracción de la clase propietaria indígena hacia actividades económicas propias de la cultura romana. Todavía estamos lejos de una romanización profunda y no parece advertirse la necesidad de la ampliación de la base social que apoye el imperio, situación que sólo se producirá posteriormente, con el advenimiento de los flavios y en circunstancias concretas. Pero las reformas iniciadas con estos últimos tardarán en consolidarse en forma de sociedad municipal. En ese lento proceso que se inicia a finales del siglo i d.n.e. y continúa a lo largo de todo el siglo II (ZAMB 9), debemos enmarcar la situación de la Necrópolis 1 del asentamiento de Los Robles, que aquí tratamos como contenido y eje arqueológico principal de nuestro discurso.

Cuando Vespasiano promueve a Hispania al derecho latino, ya varias generaciones de indígenas habían asumido como propia buena parte de la cultura romana, lo que no significa que necesariamente deban ser catalogados como netamente romanos porque a aquellas alturas de la historia del Imperio, ¿qué significaba realmente ser romano? Hoy sabemos que no es posible establecer una única definición, en todo caso podíamos ir a una complejísima tipología del ser romano, del urbanismo romano o de las propias formas de pensar en romano (Keay y Terrenato 2001; Jiménez 2008); quizás una de sus mejores expresiones figuradas pudiera ser el indígena togado que ha propuesto Le Roux (2006), un claro exponente de lo que en su momento se definió como aculturación y al que recientes propuestas se refieren como fenómenos de hibridación social (Jiménez 2008), que desde luego desmienten el carácter unidireccional que durante mucho tiempo caracterizó la construcción del concepto de romanización (Bendala 2003). No podríamos comprender sin estos nuevos planteamientos, por poner un caso, cómo en Castulo las dos necrópolis que simultáneamente están en activo durante el siglo I d.n.e.: Puerta Norte (Blázquez y Molina 1975; Canto 1979) y Cerrillo de los Gordos (Canto y Urruela 1979) presentan diferencias notables en su estructura y en la composición y cualificación de sus ajuares (Jiménez 2008), lo que recuerda extraordinariamente lo que ocurría en el mismo asentamiento durante las fases plenas ibéricas con las necrópolis del Estacar de Luciano, Molino de Caldona, Los Patos o Baños de la Muela (Blázquez 1975; Blázquez 1979; Blázquez y Valiente 1981, Blázquez y García Gelabert 1987; Ruiz 1978; Ruiz y Molinos 1993; Valiente 1999), donde se advertían importantes diferencias que sólo pueden explicarse en el marco de los distintos linajes aristocráticos que conformaban la pirámide clientelar de este asentamiento. Las diferencias en las necrópolis de las fases tardías, en un momento muy avanzado de la romanización, deben entenderse igualmente en las no homogéneas relaciones del mundo indígena del oppidum ibero, entre los propios indígenas y en su interpretación de las relaciones con Roma.

\section{EVOLUCIÓN DE LA NECRÓPOLIS 1 DE LOS ROBLES}

\section{Fase Altoimperial}

En general, la estratigrafía documentada en la zona verde JN-4 presenta características similares en toda su extensión, con abultadas superposiciones estratigráficas que han dado lugar a un enorme relleno de la depresión situada al suroeste, por cuya zona central discurre el arroyo de El Molinillo. El origen de la estratigrafía de la zona es con toda seguridad el 
propio asentamiento de Los Robles, que a lo largo de siglos ha generado continuos rellenos sedimentarios en la depresión hasta formar paquetes de hasta 2,5 metros de potencia.

La intervención arqueológica llevada a cabo en el Vial Norte, a unos 30 metros al norte de la zona de la necrópolis, demuestra que durante el siglo i el establecimiento de Los Robles se encontraba ya en plena producción de aceite y se construían la mayor parte de las instalaciones industriales y residenciales que posteriormente configurarán definitivamente el asentamiento (Serrano y Cano 2003; López et alii 2007).

Durante del siglo I el espacio entre el asentamiento situado sobre el cerro y el arroyo El Molinillo acogería algún tipo de ocupación, que ha quedado recogida en la serie de construcciones localizadas en los sondeos efectuados (cortes 102 y 104), donde se identificaron sendos muros de mampostería regular y mediana con dirección este-oeste, apoyados sobre los niveles ibéricos tardíos. En ambos casos se trata de muros que no están asociados a derrumbe alguno, ni a pavimentos bien definidos, sino más bien a suelos de tierra batida o natural, ya que es frecuente la aparición de gravas o arena finas. Esto nos ha llevado a pensar que podría tratarse de unos sencillos zócalos de aterrazamiento o contención del terreno y quizás de protección, en un punto en que el arroyo El Molinillo se encuentra muy próximo. Ello parece sugerirlo, además, que su orientación está siguiendo las curvas de nivel y serían prácticamente paralelos a otras construcciones similares localizadas en el corte 110, al otro lado del pequeño curso de agua (Fig. 5).

En conclusión, a esta fase corresponde una primera ordenación de época julio-claudia del espacio en torno al cerro Los Robles, donde, al igual que en el cerro de Cuétara, se están desarrollando actividades industriales al tiempo que debe existir un espacio residencial a juzgar por la calidad de los materiales que aparecen y que deben asociarse a la Fase I definida en la excavación del sitio en 2006 (López et alii 2007).

Durante el periodo Julio-Claudio debieron existir algunas zonas funerarias vinculadas a Aurgi que desconocemos, y de las que sólo podemos indicar la existencia de un monumento funerario turriforme, probablemente de incineración, localizado a un kilómetro al sur de Los Robles, en un punto intermedio de la calzada que parte de la ciudad hacia el norte (Pérez 1997).
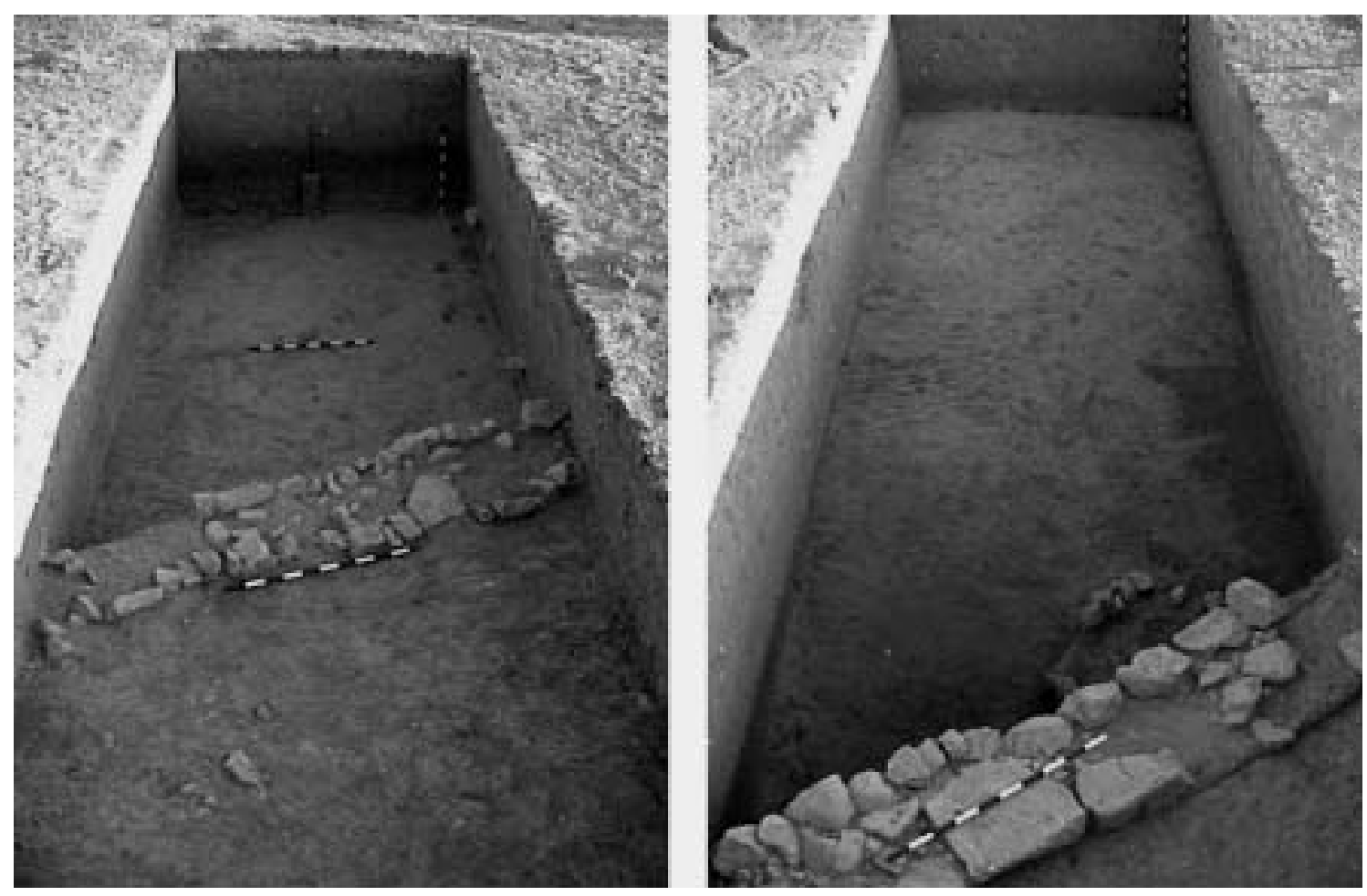

Figura 5. Construcciones julio-claudias. 


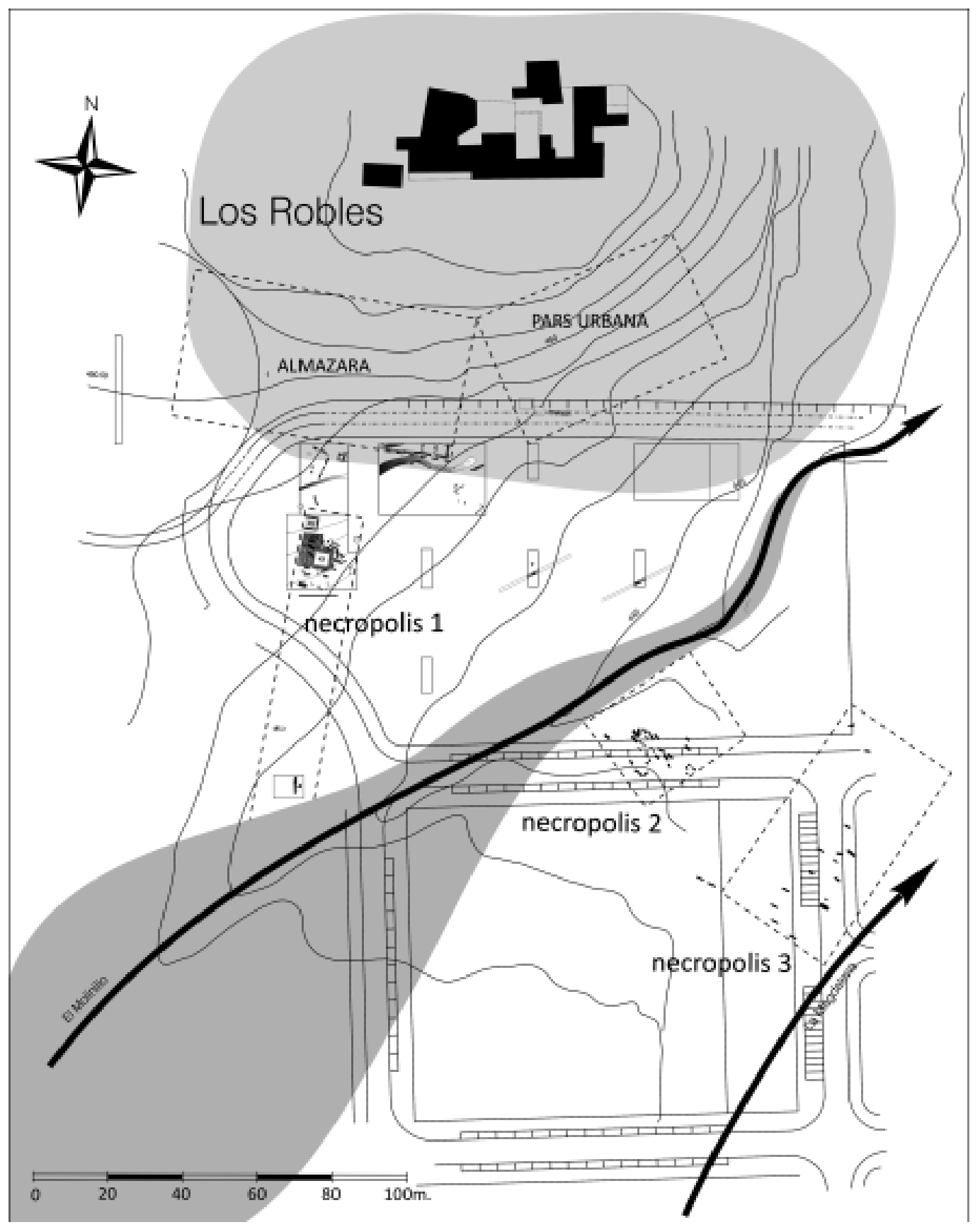

Figura 6. Localización necrópolis asociadas a Los Robles.

Hacia finales del siglo I se funda el Municipio Flavio Aurgitano, cuyas evidencias epigráficas no dejan lugar a dudas sobre la deductio (González y Mangas 1991). En Marroquíes Bajos esta fase se puede seguir a través de una serie de cambios en la estructura del poblamiento, y en el asentamiento de Los
Robles también podemos apreciar algunos elementos que demuestran el impacto de la fundación del municipio. Además, a esta fase corresponde el inicio de la necrópolis de inhumación, la Necrópolis 1, cronológicamente anterior a las necrópolis 2 y 3, y la más antigua excavada en el entorno de Los Robles. 
De todas estas necrópolis vamos a presentar los resultados de la que por el momento constituye la más antigua documentada asociada al complejo Los Robles, la Necrópolis 1, que además nos permitirá reflexionar sobre el mismo concepto de romanización, dadas las especiales características y circunstancias de su origen y desarrollo.

La Necrópolis 1 se crea sobre un espacio altamente simbólico, una suave ladera orientada al sur que domina el cauce del arroyo El Molinillo y el amplio humedal que se forma sobre un terreno arcilloso, llano y pantanoso, de pausada circulación de aguas, datos que se han visto confirmados en las intervenciones arqueológicas llevadas a cabo en el sector (Serrano et alii 2001a; Serrano et alii 2001c; Portero 2007), y es además una ladera perfectamente visible para cualquiera que se acerque desde la propia ciudad romana de Aurgi. La ordenación del espacio funerario de la Necrópolis 1 se diseñó siguiendo ejes definidos por las edificaciones julio-claudias y flavias, es decir, una orientación casi perfecta norte-sur. Inicialmente el límite de la necrópolis por el norte vino dado por la construcción de la tumba, mausoleo 223, alrededor del cual se sitúan la mayoría de las tumbas del periodo flavio-antonino. Posteriormente se amplió hacia el norte con motivo de la construcción de los monumentos 222 y 221 sucesivamente. Sin embargo, la construcción de tumbas alrededor de estos últimos es muy reducida, manteniéndose el área funeraria alrededor del 223 y desarrollándose la necrópolis hacia el sur a lo largo de los siglos II y III, hasta llegar al mismo borde del arroyo.

El eje de desarrollo de la necrópolis hacia el sur lo constituye un probable espacio abierto situado al oeste de las tumbas monumentales, lo que en nuestra opinión es un camino o calle que recorre la necrópolis desde el asentamiento de Los Robles hasta desembocar en el arroyo El Molinillo. En ese punto, el arroyo constituye una zona llana y ligeramente rehundida que provocaría su estancamiento, dando lugar a una de las pequeñas lagunillas que jalonan esta zona del piedemonte de Jaén. Esta cuestión es fundamental para la comprensión de la necrópolis. La simbología relacionada con el tránsito funerario se expresa en determinados rituales funerarios, a los que no son ajenos el propio emplazamiento del lugar; en este caso, el de la necrópolis investigada tuvo en cuenta las características del paraje al sur de Los Robles, de forma que se jugó en su diseño con un espacio cargado de simbología: el descenso al mundo de los muertos se realizaba siguiendo una ruta, una calle que descendía hacia el sur, hasta un punto en el que el arroyo creaba una laguna estacional. Las intervenciones arqueológicas en el entorno de Los Robles demuestran que el arroyo allí se ensancha como una laguna (Serrano et alii 2003; Serrano et alii 2005; Ortiz y Serrano 2008; Portero 2007), pero, sobre todo, que ese sector de Marroquíes Bajos no presenta elementos asociados a una vía que se dirija al cerro Los Robles, por lo que el camino que recorre la necrópolis muere en el propio arroyo, es decir, tras recorrer unos 90 metros hacia el sur. Las limitaciones de la intervención no permitieron en su momento aclarar algunas cuestiones que ahora son fundamentales para interpretar el conjunto funerario. Así, se tendrá que plantear ampliar la zona excavada hacia el oeste, porque podríamos encontrar en esa zona una nueva fachada de tumbas alineadas a lo largo del camino, con lo que tendríamos estructuralmente cerrada esa zona.

Durante el siglo II y hasta mediados del III se mantuvo y respetó este espacio funerario. Ello quedaría demostrado por el hecho de que los complejos estructurales 223, 222 y 221 al norte y 250 al sur, respetan el límite de la extensión de la necrópolis por el oeste y sus fachadas se alinean a lo largo de un eje norte-sur. Además de estas grandes tumbas de cuidadosa elaboración, existen otras de inhumación en fosa simple con cubierta de tégula a doble vertiente $\mathrm{u}$ horizontal alineadas con el eje del camino.

La Necrópolis 1 se organiza en un espacio aislado de la zona de hábitat pero próximo, unos 30 metros al suroeste, en un terreno de tierras negras orgánicas, sobre construcciones del siglo I apenas esbozadas en el corte 115, localizado bajo la tumba 221. Aunque no se ha excavado en extensión toda la parcela, la ausencia de estructuras funerarias en las áreas 106-107 y su presencia en los sondeos 115-116117 demuestran que se organiza en un eje norte-sur que avanza unos 90 metros al sur de los Robles hasta el arroyo El Molinillo. Allí se localiza la necrópolis 2, entre las calles B y 8, cuyo trazado apunta a que se trata de otro espacio funerario diferenciado, más que por motivos de estatus social, por una evolución originada por el agotamiento del espacio asignado originalmente, aunque no debemos descartar su origen en los cambios profundos de ritual que se producen en Los Robles con motivo del edicto de libertad religiosa de Constantino (Castro 2009). Este hecho se ve reafirmado en la disposición de muchas tumbas desde la esquina de la calle $\mathrm{B}$, desde donde cambian su orientación característica este-oeste por la de norte-sur. La diferencia de orientación entre las dos necrópolis sugiere, pese su similitud tipológica, una sucesión cronológica del ritual, que no obstante 


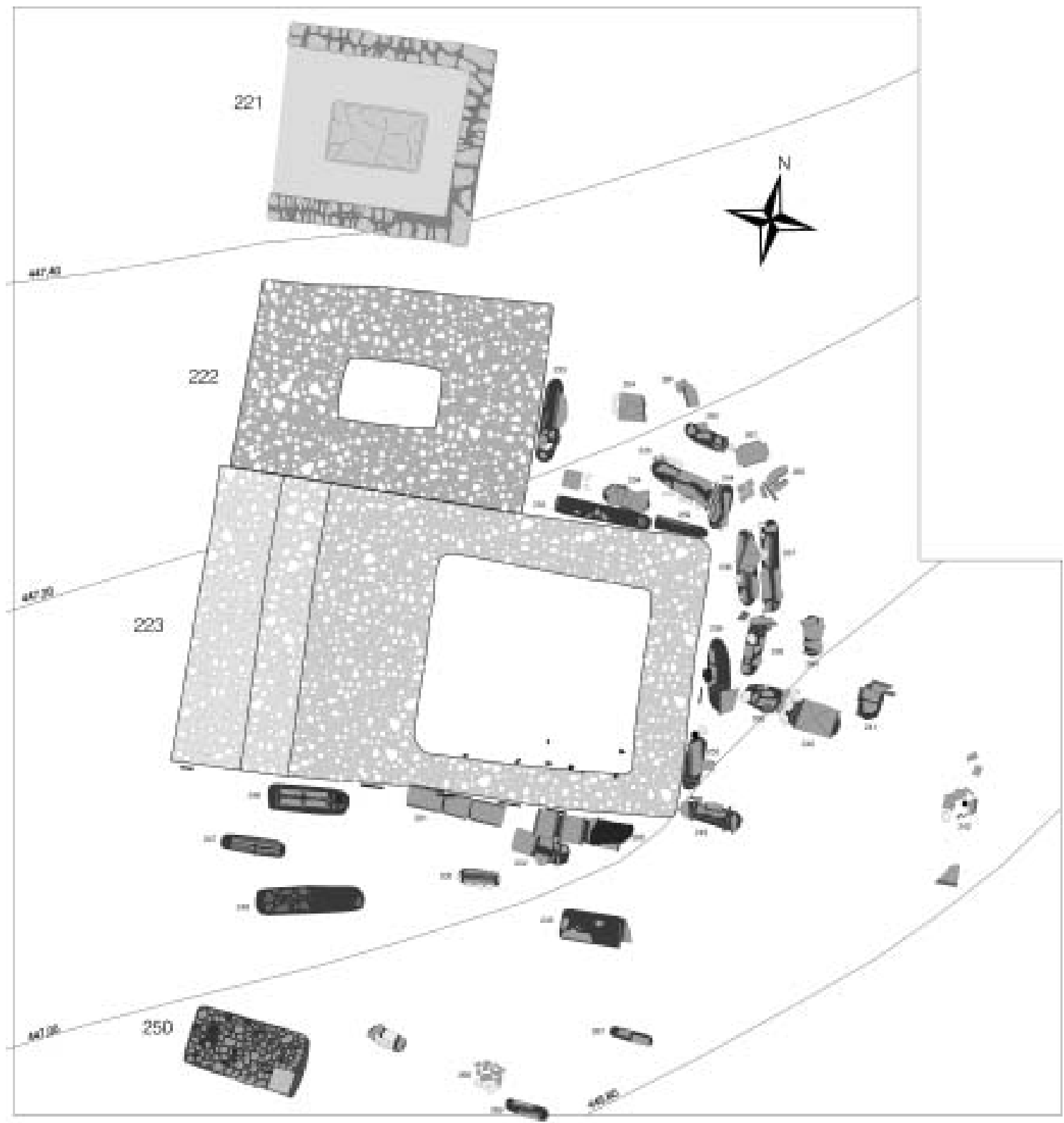

Figura 7. Planta general Necrópolis 1.

podría estar forzado por la propia organización del medio agrícola del momento.

No cabe duda de que la necrópolis fundacional, la Necrópolis 1, marca una orientación sur-norte que podríamos identificar con un camino de acceso al complejo Los Robles. Pero el recorrido de este camino se dirige desde allí hasta un punto de la cuenca del arroyo El Molinillo en que, dada la llanura aluvial natural, se abre una laguna natural. Es decir, el extremo sur de la necrópolis desemboca en un espacio estacionalmente lacustre e improductivo, lo que entendemos tiene una fuerte carga simbólica, como ya hemos indicado.

En el espacio hasta ahora excavado en este sector de la necrópolis (corte 115) se han definido un total de 35 tumbas de inhumación y 1 de incinera- 


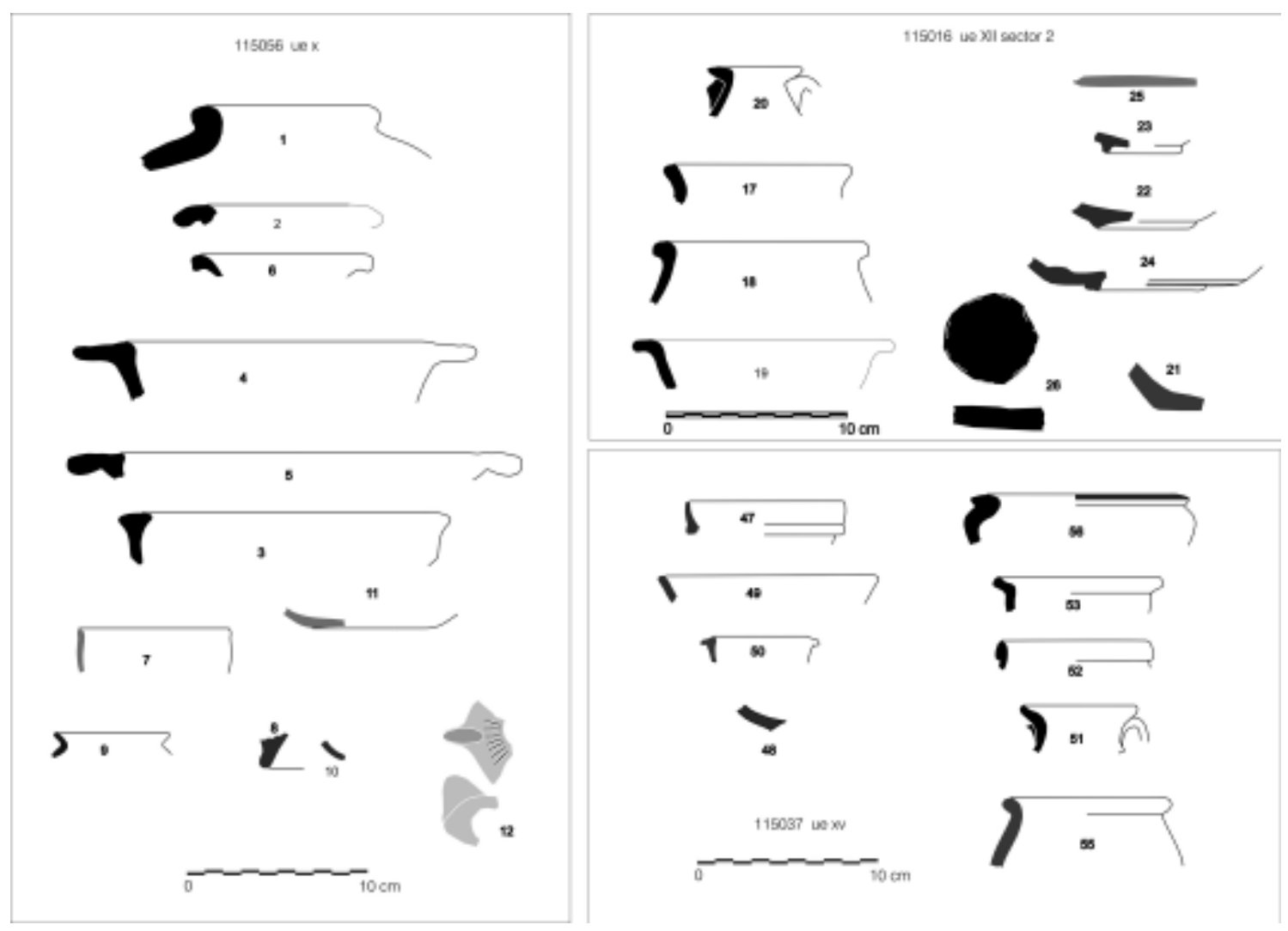

Figura 8. Materiales de la fase de actividad de la Necrópolis 1.

ción. La primera construida fue el complejo estructural 223, la única de incineración y la que ocupa mayor espacio. La construcción original debe haberse realizado a finales del siglo I en época flavia. A partir de la fundación del espacio funerario se construyen varias decenas más de tumbas, todas de inhumación, que respetan la ordenación creada por la 223, que mantiene una orientación casi perfecta hacia la calle este-oeste (la cabecera a $100^{\circ}$ este $/ 280^{\circ}$ oeste los pies) y acceso desde el oeste. Alrededor de la 223 por sus lados este, norte y sur se establecieron numerosas tumbas de fosa simple con cubierta de tégula a doble vertiente, infantiles y de adultos. Los materiales de los estratos asociados a estas tumbas (UE X y XI) indican que se realizarán desde finales del siglo I o inicios del siglo II hasta comienzos del siglo III. La necrópolis tiene pues una vida de poco más de un siglo. Predomina el repertorio de terra sigillata de Andújar, con formas características como Drag.24/ 25, Drag.15/17 de grandes dimensiones, Drag 27, etc., con pastas poco depuradas y moldes de notable menor calidad que los de buena época. A lo que hay que añadir la aparición de africanas tipo A y cerámica de cocina africana. Esto en lo que respecta al contexto estratigráfico de la necrópolis, porque en lo que hace referencia a los contenidos de las sepulturas, es decir a los ajuares funerarios, salvo alguna olla de cocina africana, están completamente ausentes. Si analizamos los materiales de ambos contextos, el funerario y el espacial externo a las sepulturas (Fig. 8), las diferencias en cuanto a su tipología, son más que evidentes.

En el sector documentado hemos definido 4 monumentos funerarios alineados a lo largo del camino que organiza el espacio funerario, las tumbas 223, 222, 221 y 250 (Fig.7), que nos van a servir para caracterizar la Necrópolis 1.

\section{Tumba 223}

Se trata de una estructura cuadrangular de $9 \times 5$ metros, con el eje mayor orientado de este a oeste. Se construye excavando una zanja en el terreno natural 


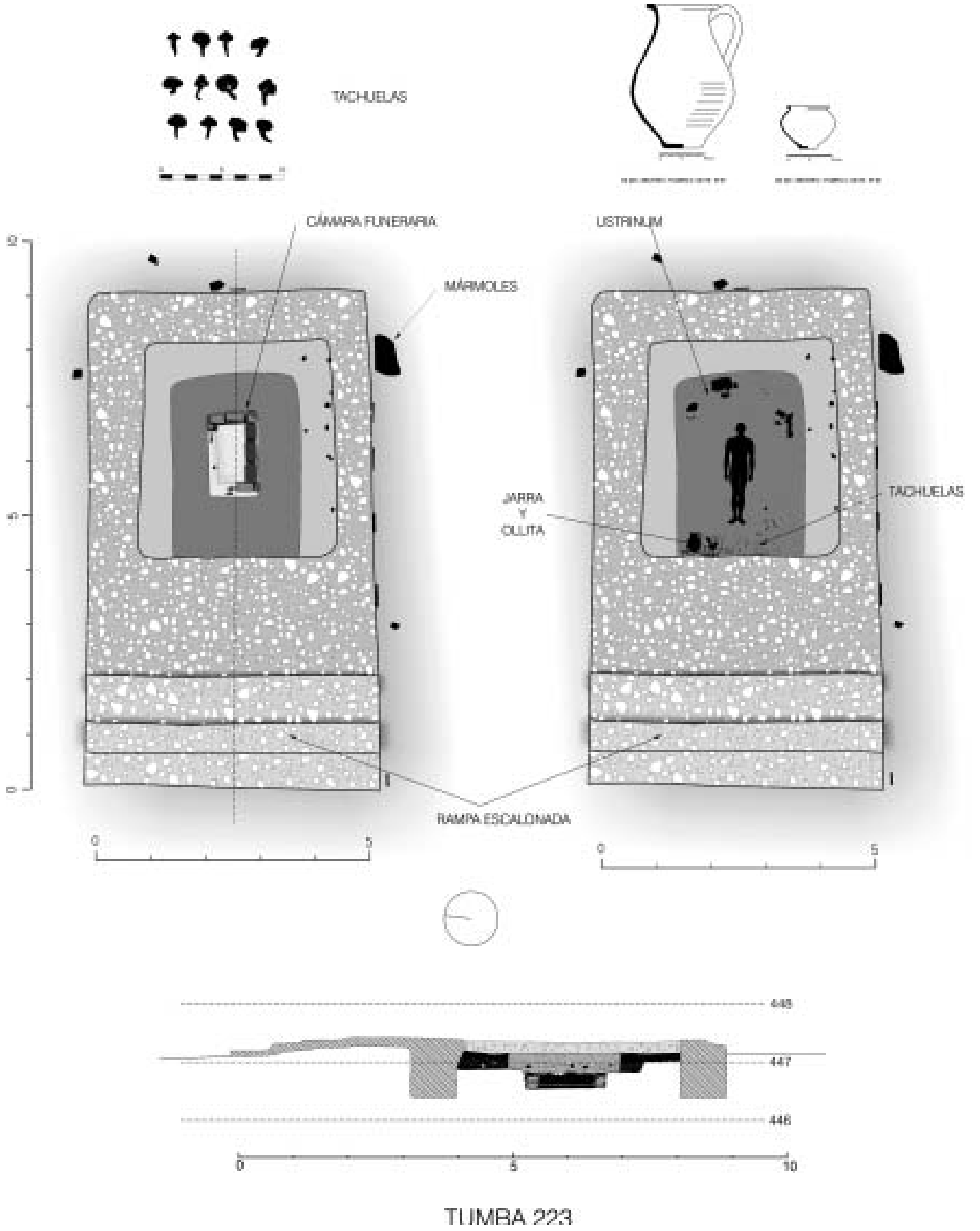

Figura 9. Monumento funerario 223.

que se rellena de argamasa de cal, arena y piedras, opus caementicium, que acaba formando un muro sólido de 1,20 metros de profundidad, del cual un metro es subterráneo. El muro de un metro de espesor rodea los cuatro lados de la estructura, pero ésta carece de suelo construido, de forma que los muros se hunden profundamente en el terreno natural con el único objeto de proteger una cámara funeraria en este espacio excavada. En el lado oeste, sin embargo, el muro-cimentación se prolonga con sucesivas capas de mortero que forman una plataforma de 4 x 5 metros ligeramente orientada hacia el oeste, de forma que 
constituye una rampa escalonada con peldaños descendentes hacia la calle de acceso.

El espacio delimitado por los cuatro muros perimetrales acota un espacio de $4 \times 3,5$ metros. Este está parcialmente vaciado para construir un gran ustrinum adosado al lado oeste, de 2,20 × 3,20 metros y unos 30 centímetros de profundidad. En este se localizaron 2 recipientes en cerámica común, una ollita de borde almendrado y una jarra de tipo Vegas 44, así como decenas de tachuelas, hasta unas 145, de hierro, muy características y agrupadas que aseguran que formaban parte de un par de caligae. Además se localizaron grandes clavos de hierro que debían formar parte del lectus funebris que contenía el cadáver durante la cremación en la pira funeraria. Finalmente, en el ustrinum aparecían abundantes cenizas y fragmentos de huesos calcinados. La distribución de estos elementos se produce alrededor del ustrinum, quedando la zona central sin apenas elementos. Esta clara ausencia se explica en la limpieza de la estructura tras la cremación para poder excavar una cámara funeraria.

La cámara tiene 1,5 × 1 metros, construida con ladrillos unidos con argamasa con técnica de soga y tizón, estaba totalmente revestida de mortero en paredes y suelo, alcanzando una profundidad de unos 40 centímetros bajo el ustrinum. La cámara había sido expoliada en época romana bajoimperial, a juzgar por los destrozos en las paredes de ladrillo, y en su relleno apenas aparecieron un anillo de oro deformado por el calor, un disco de plomo y el sello de una botella o unguentario. El ritual seguido en la incineración y el proceso de construcción de la tumba, sobre la pira, no es diferente de los que caracterizan muchos enterramientos de épocas ibérica plena y tardía.

Estratigráficamente, la estructura del monumento se construyó antes de la cremación. La evidencia procede de la propia técnica de construcción con opus caementicium. Este se vertió directamente sobre la zanja perimetral excavada en los rellenos de tierra orgánica natural, que por su debilidad se desmorona rápidamente. Por ello, el mortero adopta la forma de la zanja y sin encofrar, de paredes ligeramente irregulares y con una apertura en su parte superior que no se podría haber producido de haber estado excavado el ustrinum.

No tenemos datos significativos que nos indiquen cuál sería el aspecto que tendría la estructura emergente del monumento. El expolio de la necrópolis en época bajoimperial, momento en el que se saquearon los materiales nobles del conjunto para reaprovecharlos en otras tumbas o en el asentamiento Los Robles, sólo nos permite reconstruir algunos aspectos. Así, por ejemplo, todo el conjunto estaba revestido de placas de mármol de color azul con cenefas rosadas, horizontales en los laterales, y probablemente recubriendo la superficie de la estructura. Muchos de estos fragmentos se recuperaron durante la excavación situados en su posición original en las paredes externas de la estructura y en el interior de ella, pero también otros grandes fragmentos aparecieron dispersos en los alrededores, en los cortes 114 y 110 . Por otro lado, los restos de la estructura de mortero no presenta huellas de haber soportado una estructura emergente elevada que cubriera la tumba, y tan sólo los peldaños de acceso a esta por el oeste sugieren la posibilidad de un sitio al que se recurriera ocasionalmente. Tampoco se conservaban elementos que pudieran corresponder a una cubierta tejada, ni los muros perimetrales presentan arranque de muros. Por otro lado, la fosa de expolio de la cámara se ajusta casi a la perfección al tamaño rectangular de esta, lo que sugiere la existencia de una estructura emergente que señalara el punto. Probablemente hemos de pensar en una pequeña ara central en la estructura, destinada a las ceremonias de homenaje al difunto.

En lo que respecta a la cronología de este monumento, entre el relleno de la zona rehundida del ustrinum que sella la cámara se hallaban cerámicas de barniz rojo sigillata del taller de Andújar, que corresponden a época flavia, es decir, debemos fechar esta primera estructura a finales del siglo i d.n.e. Los recipientes del ustrinum, las ofrendas del ritual de cremación, son: jarra de pasta clara tipo Vegas 44, con cronología entre época flavia y mediados del siglo II, y una pequeña olla de cocina que responde a un tipo mas antiguo, las ollas de borde almendrado, que no obstante pueden alcanzar los siglos I-II (Fig. 10).

Alrededor de la tumba 223 se realizan una serie de enterramientos de inhumación que tienen como punto de referencia esta estructura, disponiéndose las tumbas de norte a sur y este a oeste según el lado de la tumba en el que se localizan. Prácticamente todas las tumbas se construyen en fosa simple con cubierta de tégulas a doble vertiente o tégulas horizontales. Todas se alinean a lo largo de alguno de los lados sur, este y norte, quedando el acceso por el oeste despejado de enterramientos. Se observó la presencia de ofrendas en superficie asociadas a algunas tumbas infantiles. Se trata de vasos cerámicos de pasta clara sin tratamiento decorativo. Destaca la ausencia generalizada, ya advertida, de materiales cerámicos de calidad, como recipientes de vidrio, metal o terra sigillata.

Esta tumba ordena con toda claridad el espacio funerario, y es evidente que el resto de las sepulturas de inhumación de este momento se construyen buscando el mayor nivel de proximidad a ella, de 


\section{COMPLEJO ESTRUCTURAL 223}

\section{UE VI /UE VI}

T
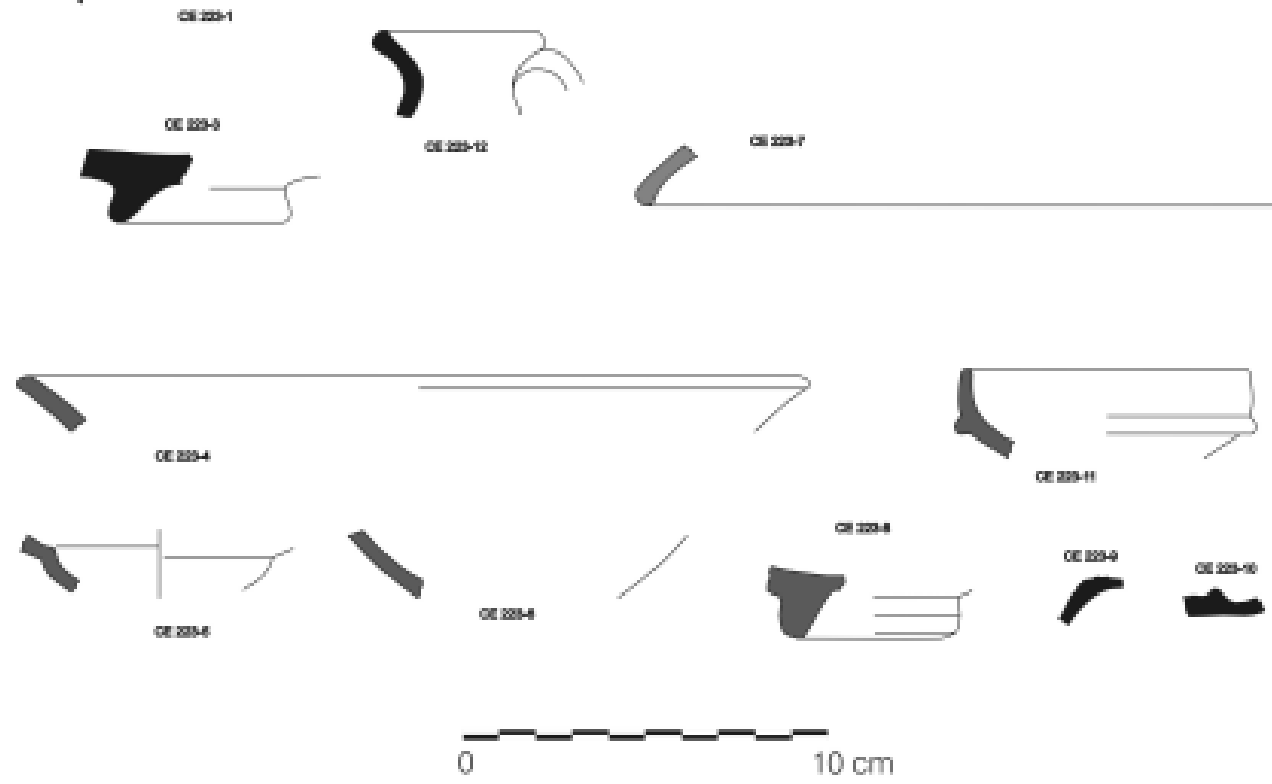

UE II / UE IV / UE X

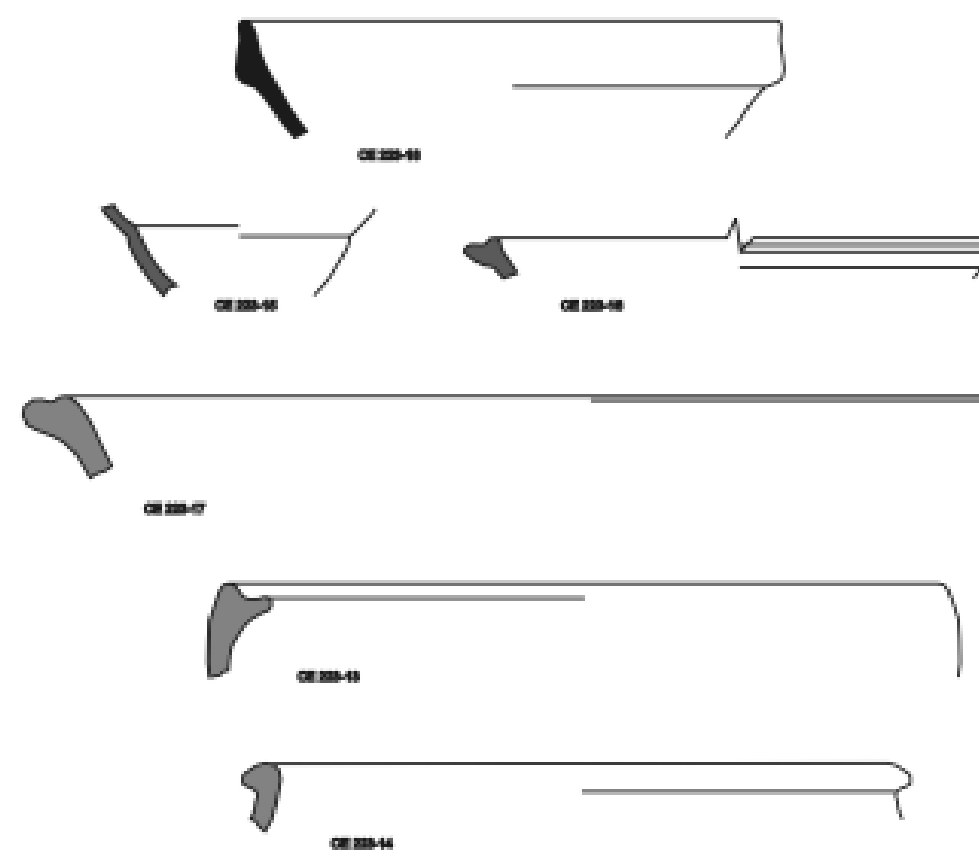

Figura 10. Materiales asociados al monumento funerario 223. 


\section{TUMBA 202}

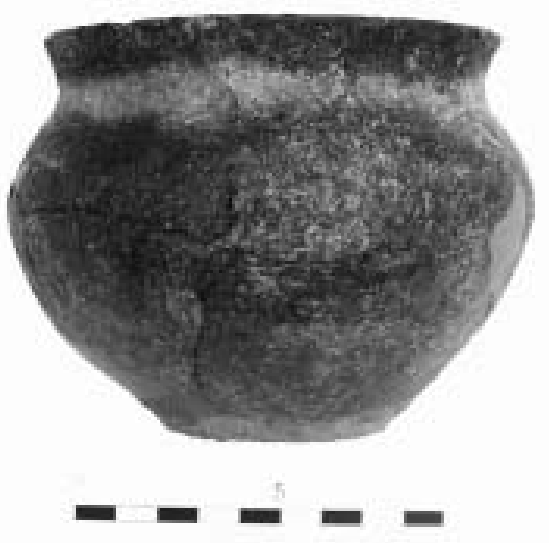

TUMBA 242

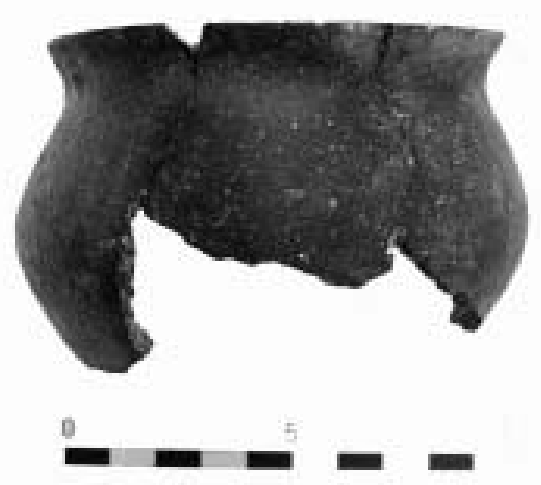

TUMBA 241

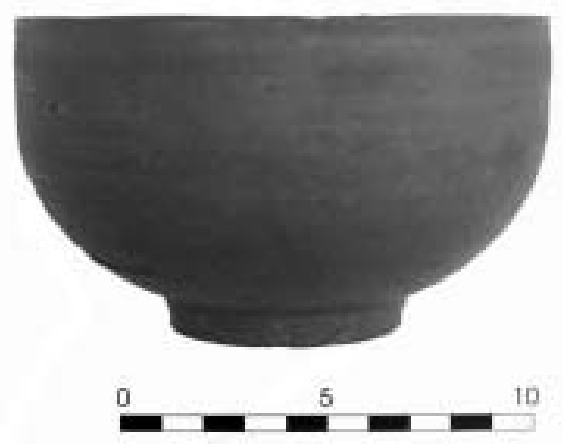

TUMBA 253

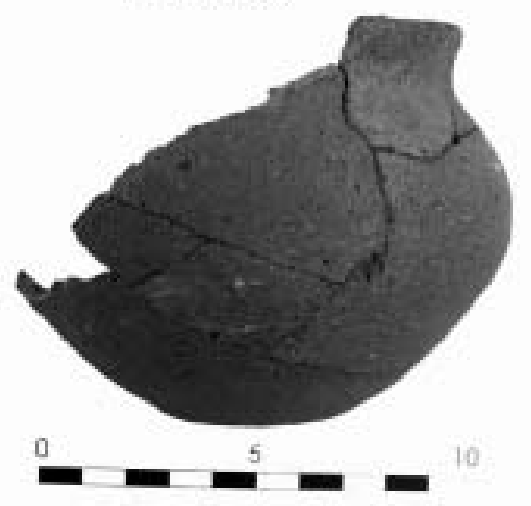

Figura 11. Materiales asociados a ofrendas de tumbas.

hecho algunas prácticamente se adosan a la principal, aunque sin llegar a alterarla mínimamente.

Aunque no se excavaron todas las sepulturas, porque una parte de la necrópolis se dejó en reserva para el momento de su puesta en valor, las excavadas presentan ajuar en el interior de la estructura. Por ejemplo la tumba 201 es una cista de ladrillos cuadrangulares y cubierta de tégulas horizontales, con una inhumación decúbito supino frontal con brazos a lo largo del cuerpo y cabecera al este, contenía un ajuar consistente en una ollita de cerámica grosera a la altura de las piernas. La tumba se construyó adosada al muro sur del complejo estructural 223. La tumba 200 es una tumba infantil de tégulas a doble vertiente. En la base, las tégulas están calzadas con piedras y barro. La tumba se encaja en una pequeña fosa donde apoyan las tégulas, que una vez rellenada apenas mostra- ría unos centímetros de tégula al aire. Otras tumbas no excavadas, como la infantil 242, presenta ajuar en superficie de un vaso hemiesférico común con una ficha de hueso en su interior, mientras que la 253 tenía en la cabecera una olla de cocina (Fig. 11).

\section{Tumba 222}

Debemos considerar de esta fase altoimperial el monumento funerario 222, construcción de mortero de cal y arena trabando una masa informe de piedras pequeñas, que constituyen una argamasa débil, que no es propiamente opus caementicium, careada en su perímetro exterior y en su cámara central. Se trata de una estructura que ha sufrido varias reutilizaciones, de modo que apenas si podemos intuir su estructura 

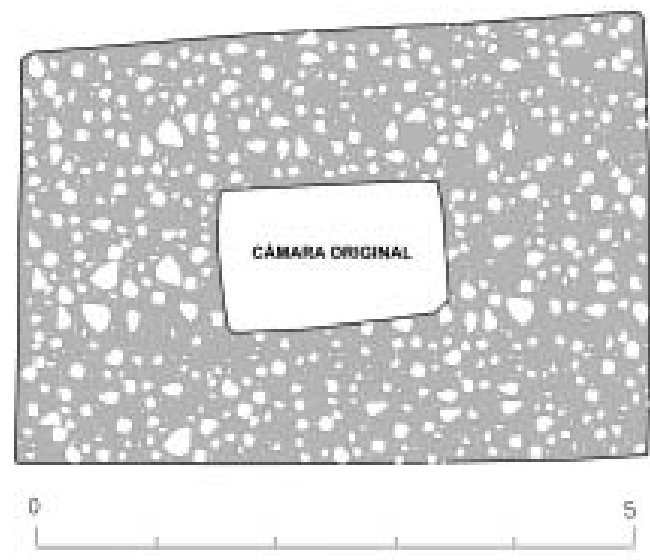

FASE ALTOMPERLAL
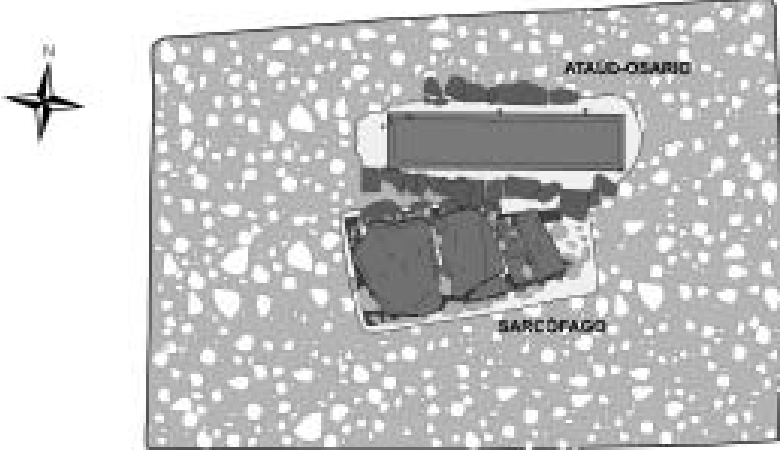

0

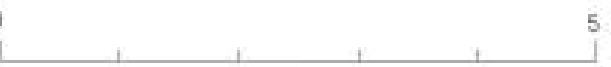

FASE VISIGCOA

Figura 12. Monumento funerario 222.

interna original. Inicialmente se construye la estructura tal y como se conserva, es decir, una plataforma rectangular de unos 5,2 x 3,8 metros cuyo eje más largo es este-oeste, elevada 0,5 metros sobre la superficie de construcción, con revestimiento estucado en el exterior y probablemente en su superficie. En el centro se construye una cámara sepulcral de 2,5 x 1 metro. No se conservan elementos relativos a la decoración que presentara, pero este monumento funerario mantiene proporciones propias de estructuras conocidas de tradición indígena. El lado sur de la estructura se adosa al muro norte del CE 223, y su derrumbe parcial en época bajoimperial se extiende sobre ese muro, lo que estratigráficamente demuestra que es posterior.

Desconocemos el ritual de enterramiento y el número de individuos porque la cámara está reacondicionada en época visigoda, y apenas se conservan elementos originales, pero nos inclinamos a pensar que se tratase de una tumba de ritual de incineración, dadas las escasas dimensiones de la cámara original, que acogería los restos de un solo individuo y su ajuar. La reestructuración visigoda amplió el espacio de la cámara central para poder acoger un sarcófago de piedra caliza, por lo que no se conservan apenas evidencias de la tumba precedente.

A partir del siglo $\mathrm{v}$, sobre la tumba altoimperial se instalan dos nuevas estructuras de enterramiento que arrasan la construcción original y le dan un nuevo carácter. La cámara central se acondiciona como una tumba individual de cierto rango. Se construye un sarcófago de piedra a base de losas de caliza y fragmentos de otros elementos constructivos colocados en la base y los laterales de la antigua tumba 222. Esta tumba finalmente acogió dos enterramientos de adultos. El más antiguo aparece como osario dispuesto a los lados del segundo enterramiento. Este es un individuo adulto en posición decúbito supino frontal, cabecera al oeste. Presentaba como ajuar una botella de cerámica con la pasta clara y tipología característica tardorromana y dos anillos de oro con engarce de pasta vítrea.

Junto al sarcófago se excavó una fosa rectangular en el relleno de argamasa original. Dentro se colocó un ataúd de madera que contenía un osario de unos 22 individuos (Fig. 12).

\section{Tumba 221}

De entre las tumbas que se construyen en este periodo destaca el complejo estructural 221 (Fig. 13). Se trata de una tumba de compleja elaboración, alineada a la calle y a 1 metro al norte del monumento 222. Se construye una estancia o recinto cuadrangular de 2,6 $\times 3,2$ metros a base de mampostería regular desbastada de piedras medianas, abierta por el oeste, de forma que el acceso es directo desde la calle. Por los restos conservados pensamos que se trataría de una simple cerca de mampostería de escasa altura, lo suficiente para reservar privadamente el espacio. Hipótesis esta que se ve corroborada, como veremos mas adelante, por la ampliación de este perímetro en época tardorromana con una valla de madera que lo cierra completamente. Dentro del recinto se construye una estructura central rectangular, 



Figura 13. Monumento funerario 221.

de forma tabular, una mensa, con mortero de cal y arena, opus signinum, de unos 1,20 x 1,70 metros de este a oeste, dejando entre esta y el muro perimetral un pequeño espacio de tránsito de apenas 1 metro. Bajo la mensa se abre una fosa de 1 x 1,7 metros donde se construye una cista de ladrillos a soga y tizón trabados con barro, y dentro de la cista se deposita un sarcófago de plomo con un individuo infantil. La cista se sella con losas de cerámica y todo el conjunto queda sepultado bajo capas sucesivas de cerámica, piedras y tierra batida hasta la superficie final de opus signinum.

Este espacio no acoge ningún otro enterramiento hasta mucho después, cuando hacia el siglo v esta estructura es parcialmente reutilizada y el espacio, diseñado originalmente para contener un enterramiento infantil, sigue siendo usado para acoger tumbas de niños de corta edad. Pero ahora se redefine el espacio, de forma que si antes se accedía desde el oeste, ahora se cerca el lado oeste prolongando el muro de piedra con una estructura de madera de la que se han localizado numerosos clavos; el fondo sería un espa- cio rectangular de unos 5 metros de este a oeste por 2,6 de sur a norte. El acceso se hace desde el sur, rompiendo parcialmente el muro sur de piedra. Así, en este espacio se ubicarán nuevas tumbas como la 251 , enterramiento doble infantil que afecta parcialmente al muro sur, o la 232. La estructura tipo men$s a$ se reeleva con ladrillos y mortero unos $30 \mathrm{~cm}$ sobre el suelo de la estancia.

Tipológicamente existen numerosos paralelos que se pueden fechar entre los siglos III y v d.C, siendo más frecuentes en época tardorromana, pero existen algunos sarcófagos de cronología más temprana (Palol 1972; González 2001). Aunque los ajuares de joyería están sin estudiar, el contexto estratigráfico nos enmarca esta estructura entre mediados del siglo in y comienzos del siglo III. En el contexto material de la necrópolis, sabemos que su origen se produce en época flavia y su momento de mayor auge en época antonina, en cambio el momento final parece más difuso. Cuando el monumento funerario 221 se amplía, cerrando el recinto con una cerca de madera que duplica el espacio, se hará ya ocupando la calle de 
acceso a la necrópolis, al oeste. Ese momento presenta cerámicas características de mediados del siglo III en adelante. Una moneda, aparecida en el ámbito de la tumba 221, acuñada en época de Galie$\mathrm{no}^{8}$, nos fija un momento de mediados del siglo III en que podemos considerar desarticulada la calle y la necrópolis. La conclusión es que ese monumento se construyó entre mediados del siglo in y comienzos del III. La aparición de la estructura tabular de esta tumba no debe interpretarse necesariamente como una mesa de ceremonial cristiano, de hecho los rituales relacionados con los banquetes funerarios recordatorios del difunto forman parte de la tradición romana y son adaptados al ritual cristiano (González 2001).

\section{Tumba 250}

Se trata de una tumba de inhumación excavada en el sustrato sedimentario orgánico de época altoimperial que acoge una cista elaborada con ladrillos dispuestos a soga y tizón y trabados con barro. Esta presenta forma ligeramente trapezoidal, de 2,20 x 1 metro, y acoge un enterramiento en posición decúbito supino frontal, con los brazos cruzados sobre el pecho, con un completo ajuar en el interior: botella y vaso de vidrio en la cabecera, aplique de bronce sobre el pecho, moneda en la boca y ungüentario cerámico fusiforme en los pies. Respecto del ajuar, el elemento que ofrece mejor cronología es desde luego la moneda de Antonino Pío (138-161) ${ }^{9}$. El ungüentario de vidrio, tipo Isings 60 , se fecha también a mediados del siglo II, al igual que la olla de labio almendrado. El ungüentario fusiforme cerámico representa tipos ligeramente más antiguos, que no obstante tampoco son extraños en el siglo II (Fig.14).

La cista aparece sellada por una serie de losas de cerámica y piedra, sobre las que se deposita a los pies sendos recipientes cerámicos de cerámica común. Desde este nivel se construye un cipo de señalización a base de losetas cerámicas de 30 x 30 centímetros hasta alcanzar 0,50 metros de altura. Finalmente la fosa se rellena con capas sucesivas de piedras y tierra negra del lugar, hasta formar un lecho homogéneo de 2,20 x 1,20 metros, señalado por el cipo, en el lado sur de la cabecera, situada al este de la tumba. Esta estructura presenta una gran similitud con

\footnotetext{
${ }^{8}$ A/. GALLIENVS AVG Busto del emperador a der., con corona radiada. R/ IOVI (.......). Pantera a izq. Catalogación: Antoniniano. Emisor : Galieno. Cronología: Galieno (260-268). Emisiones del bestiario (267-268). (RIC V)

${ }^{9}$ A/. Busto laureado del emperador a der. R/ Figura femenina de pie. Catalogación: As. Emisor: Antoninus Pius. Ceca: Roma. (RIC III).
}

el CE 221, a excepción de la cubierta de argamasa en mensa y el espacio delimitado alrededor. El uso de losas cuadrangulares de cerámica en la cubierta, idénticas a las de la tumba 221, sugiere el encargo específico o reutilización de un mismo punto de material de construcción, o incluso el expolio de otra estructura, por lo que suponemos que se tratan de construcciones muy próximas en el tiempo (Fig. 21).

En conclusión, durante el siglo III el ritual funerario sigue siendo bastante homogéneo, y aún no se advierten cambios en la orientación de las tumbas ni en la presencia de ajuares y ofrendas. A este periodo deben corresponder las aperturas de nuevas necrópolis hacia el sureste (necrópolis 2), donde en un vial de la urbanización ya se documentó una necrópolis con inhumaciones en tumbas de tégulas a doble vertiente, orientadas de norte a sur, frente a otras superpuestas orientadas de oeste a este, claramente tardorromanas y visigodas. Probablemente esta ampliación de la zona funeraria, manteniendo el ritual romano, debe ponerse en relación con el momento de consolidación de la propiedad de la villa Los Robles, cuando sobre la base de la crisis del siglo II se reconstruye el complejo residencial e industrial hacia un espacio palaciego progresivamente desvinculado de Aurgi (Fig. 17).

\section{FASE BAJOIMPERIAL}

La información obtenida para esta fase es la más exigua de todas las recogidas. El motivo es que la superposición estratigráfica ha situado en la parte más alta estos niveles, que están hoy en contacto con la tierra orgánica superficial y removida por los cultivos. Así, la fase final de ocupación funeraria del entorno de Los Robles nos ha llegado con construcciones mal conservadas que, sin embargo, demuestran que la actividad, ocupación y explotación de la zona de Los Robles se mantuvo con pujanza durante los siglos III$\mathrm{v}$; buena prueba de ello es que la almazara del asentamiento sigue activa durante todo este periodo (López et alii 2007). Se ha sugerido por algunos autores su conversión en un centro de poder religioso, proponiendo la reconstrucción de una parte del sitio para acoger una basílica paleocristiana (Castro 2009).

Algunos materiales de construcción decorados localizados en distintos puntos de Marroquíes Bajos, y entre ellos el propio cortijo (encontramos restos de este tipo de materiales en los muros de la vivienda islámica CE 214, con una cronología hacia el siglo IX), demuestran además, que durante este periodo Los Robles debió ser un centro de control del territorio 

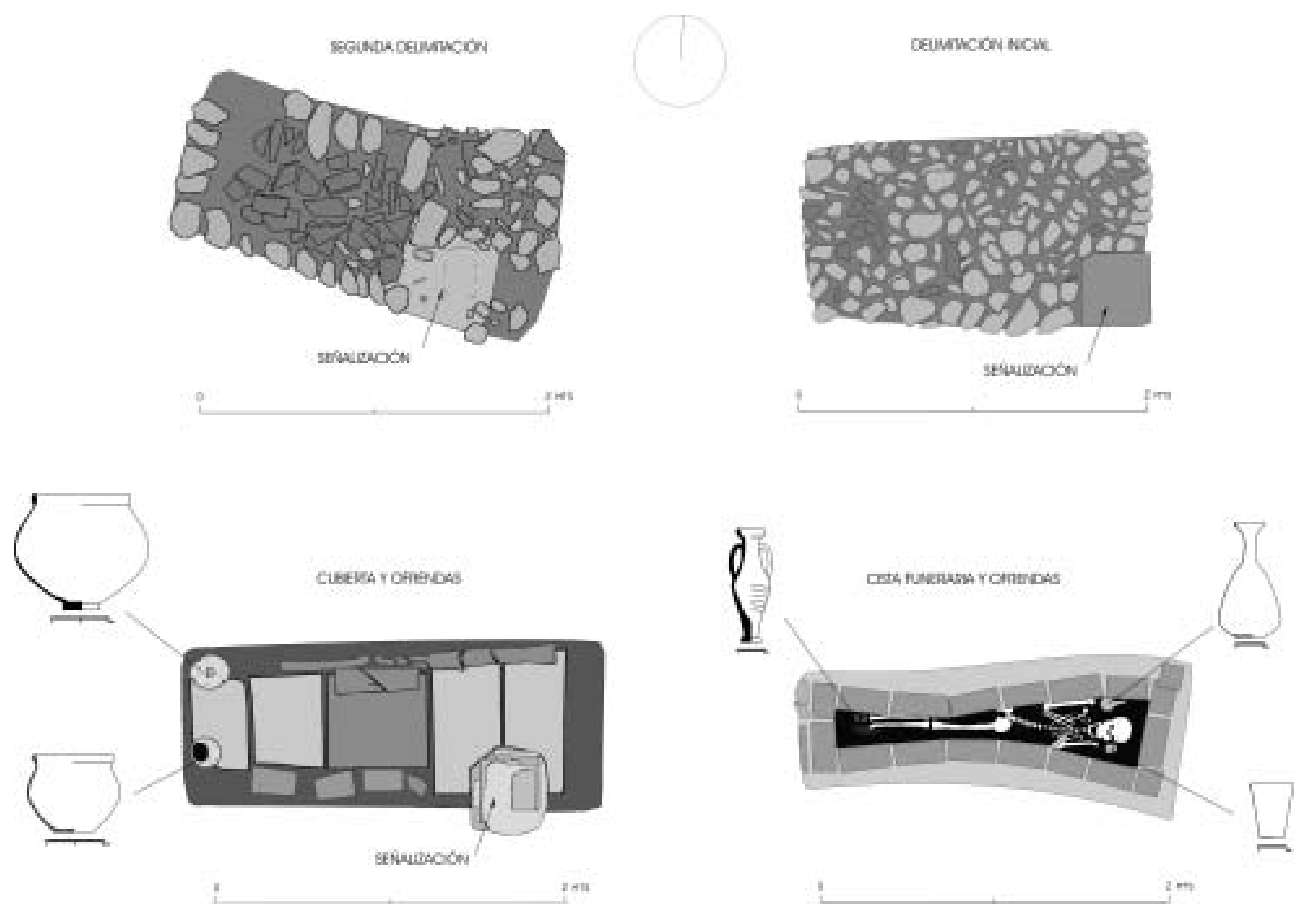

Figura 14. Tumba 250.

no solo por su posición estratégica, sino también por constituirse en un centro de poder administrativo y religioso. Así, los restos de capiteles y pilastras visigodos hallados durante las intervenciones de los años 90 en la urbanización SUNP-1 y RP-4 sugerían la existencia de una iglesia en los entornos o en el mismo cortijo, edificio que sería demolido en época islámica, hipótesis que se ha visto confirmada en la más reciente intervención arqueológica en el sector (López et alii 2007).

Durante el Bajo Imperio la Necrópolis 1 se habría abandonado prácticamente, prefiriéndose el enterramiento en alguna de las otras necrópolis distribuidas alrededor. Sólo a partir de un momento indeterminado, probablemente inicios del siglo $\mathrm{v}$, volvemos a encontrar nuevos enterramientos allí.

El núcleo principal de la necrópolis debía seguir siendo un espacio sagrado funerario, pero ya no se reconocen nítidamente los límites del camino de acceso ni las estructuras precedentes. Probablemente a ello contribuiría el hecho de que toda la zona debía presentar el aspecto de una pequeña elevación en la que apenas se diferenciarían las grandes estruc- turas más antiguas, que, en el caso del monumento 223, ya había sido expoliado. Este aspecto de abandono estaría motivado por el hecho de que, a priori, no parecen existir en la necrópolis enterramientos de los siglos IV-V. Durante esta fase, que coincide con el edicto de Constantino de 313 que autorizaba el culto cristiano, parece haberse preferido nuevas zonas de enterramiento que no coincidieran con los enterramientos de rito pagano, momento en el que se desarrolla otra zona funeraria, la Necrópolis 2.

Así, en la Necrópolis 1 sólo se han identificado 12 estructuras funerarias que corresponden a enterramientos de rito cristiano y técnica constructiva característica tardorromana o visigoda. Es decir, con un lapsus de tiempo importante entre los enterramientos de necrópolis inicial de los siglos I-III y el siglo V-VI. De entre todas las tumbas, destaca el CE 222, que se encuentra en una posición central respecto de las demás y en general sobre la antigua necrópolis. Su posición privilegiada, reutilizando un monumento funerario anterior, se demuestra en la calidad de los ajuares que presenta y en el cuidado y elaboración de la propia tumba (Fig. 12). A su alrededor se 

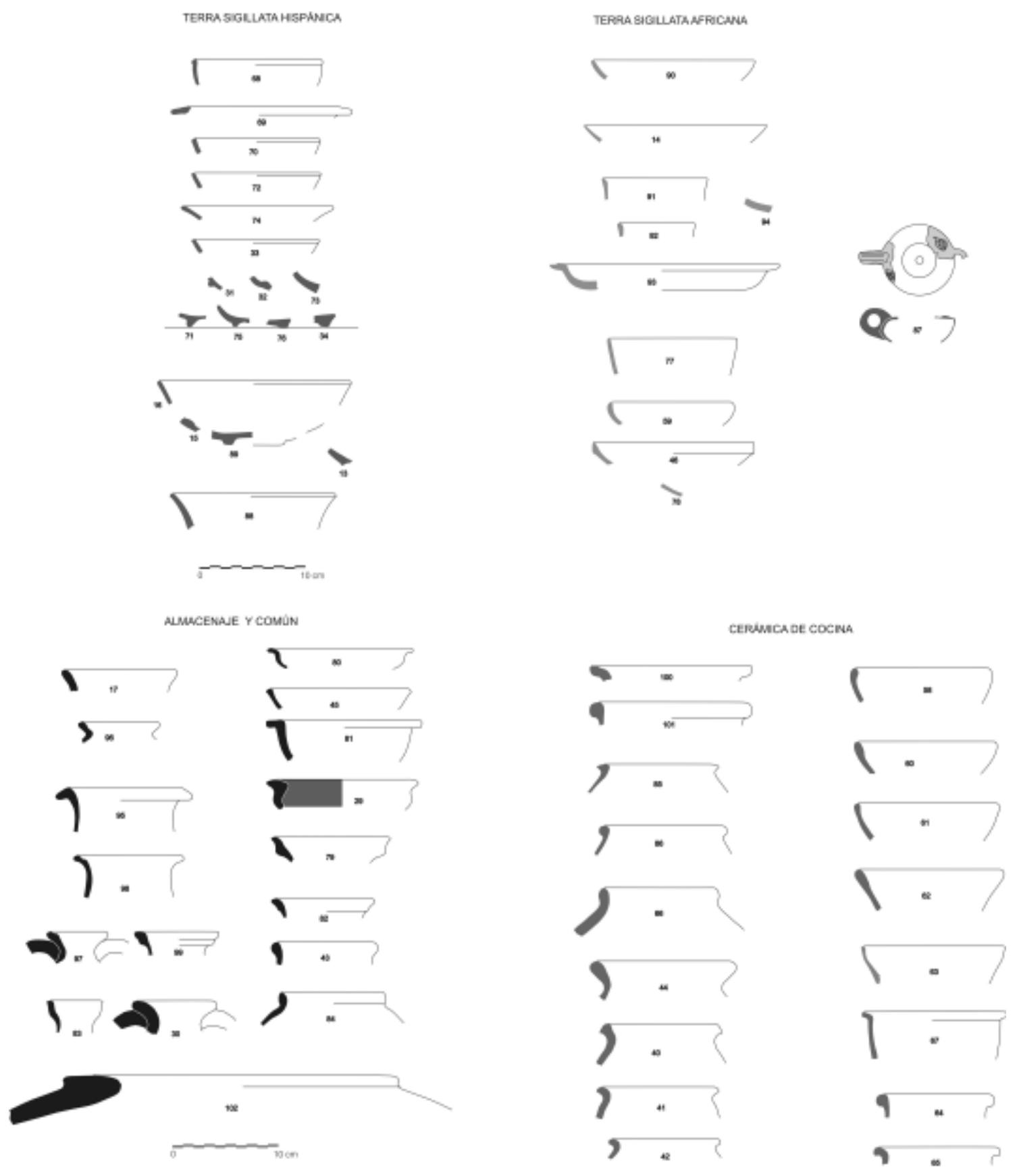

CORTE 115 - UE VII

Figura 15. Materiales asociados al abandono de la Necrópolis 1.

realizaron una serie de enterramientos en fosa simple y fosa simple con cubierta de losas de piedra, con cabecera al oeste, que a diferencia de las tumbas de la fase altoimperial tiene una orientación diferente al noroeste-sureste o norte-sur. Las tumbas forman pe- queñas concentraciones: cuatro al sur, sobre el antiguo monumento 223, y tres al norte, en el pasillo entre las tumbas 221 y 222.

Se excavan hasta 4 tumbas sobre los peldaños de acceso al complejo estructural 223 , rompiendo la 

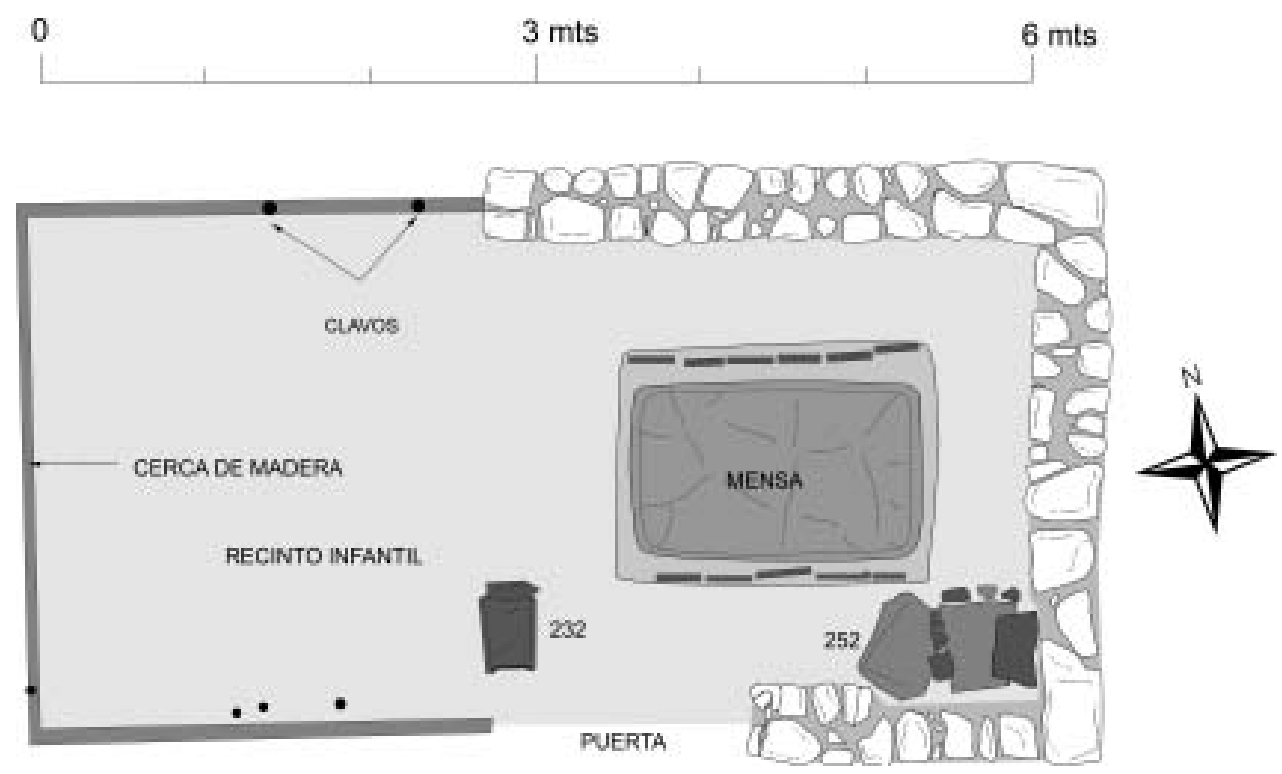

Figura 16. Ampliación visigoda del monumento funerario 221.

estructura de hormigón romano (tumbas 227, 228, 229,230 ), que este periodo apenas sería un túmulo en ruinas, de donde se habrían extraído la mayoría de los revestimientos de mármol. Al norte, en el pasillo entre los monumentos 221 y 222 , se instalan dos tumbas individuales (tumbas 224 y 225) y se vacía parte del relleno de la estructura 222 para construir un osario junto a la tumba principal 222. Además, dentro del recinto del antiguo CE 221 se siguen realizando enterramientos infantiles (tumbas 252 y 232).

Como hemos referido, a lo largo del siglo iv se desarrolla una nueva necrópolis, la Necrópolis 2 (Fig. 6), al otro lado del arroyo, siguiendo un eje nordeste-suroeste, enmarcada en una zona estrecha delimitada entre los arroyos El Molinillo y La Magdalena, en una área muy próxima a su confluencia. Esa pequeña elevación, de apenas 70 metros de anchura, acoge una necrópolis cuyas tumbas, unas 35, excavadas en una calle, se disponen a lo largo de la margen derecha del arroyo El Molinillo, pero ya apreciamos en ellas un cambio de orientación, de noroeste a sureste. Todas corresponden a inhumaciones con construcciones funerarias de tégulas a doble vertiente apoyadas en prefosa que delimita una fosa simple excavada en las margas, que puede tener o no tratamiento del suelo con tégulas. Las inhumaciones carecen de ajuares y todas presentan el individuo en decúbito supino frontal. Como detalle distintivo de esta necrópolis es frecuente el hallazgo de cubierta a doble vertiente, donde las tégulas se han recortado para encajarse unas con otras y dar mayor esta- bilidad a la cubierta. En algunos casos las tumbas se delimitaban mediante una acumulación de piedras, que constituían un túmulo de cantos de río perfectamente observable en superficie (Fig. 17).

Posteriormente, el espacio funerario se amplía hacia el sureste con más de 20 enterramientos de época tardorromana y visigoda, que ocupan un espacio marginal por su frecuente encharcamiento. Estas tumbas, dadas sus características y particularidades, se han definido como Necrópolis 3. Se encuentran dispersas a lo largo de un amplio espacio, que viene a coincidir con el eje más elevado entre las cuencas de los arroyos La Magdalena y El Molinillo. Las tumbas de inhumación presentan fosas simples sin cubierta, fosas con cubierta de losas de piedra, cistas de ladrillo con cubierta de losetas a doble vertiente y alguna otra variación tipológica. En general es frecuente la reutilización de material de construcción, a diferencia de las tumbas de la Necrópolis 2, todas con tégulas homogéneas y cuidadas. También a diferencia de esa otra zona funeraria, es frecuente la aparición de ajuares en las inhumaciones. Fundamentalmente se trata de pequeñas jarritas de cocina, cuentas de collar de pasta vítrea, pendientes y anillos de bronce, alfileres y broches. El conjunto, aún a falta de cronologías absolutas, se puede adscribir al periodo tardorromano y visigodo.

Con todo, estos enterramientos no son los últimos de rito cristiano que documentamos en Marroquíes Bajos. Desde las primeras campañas de excavación se vienen excavando varias zonas de necrópolis con esta 

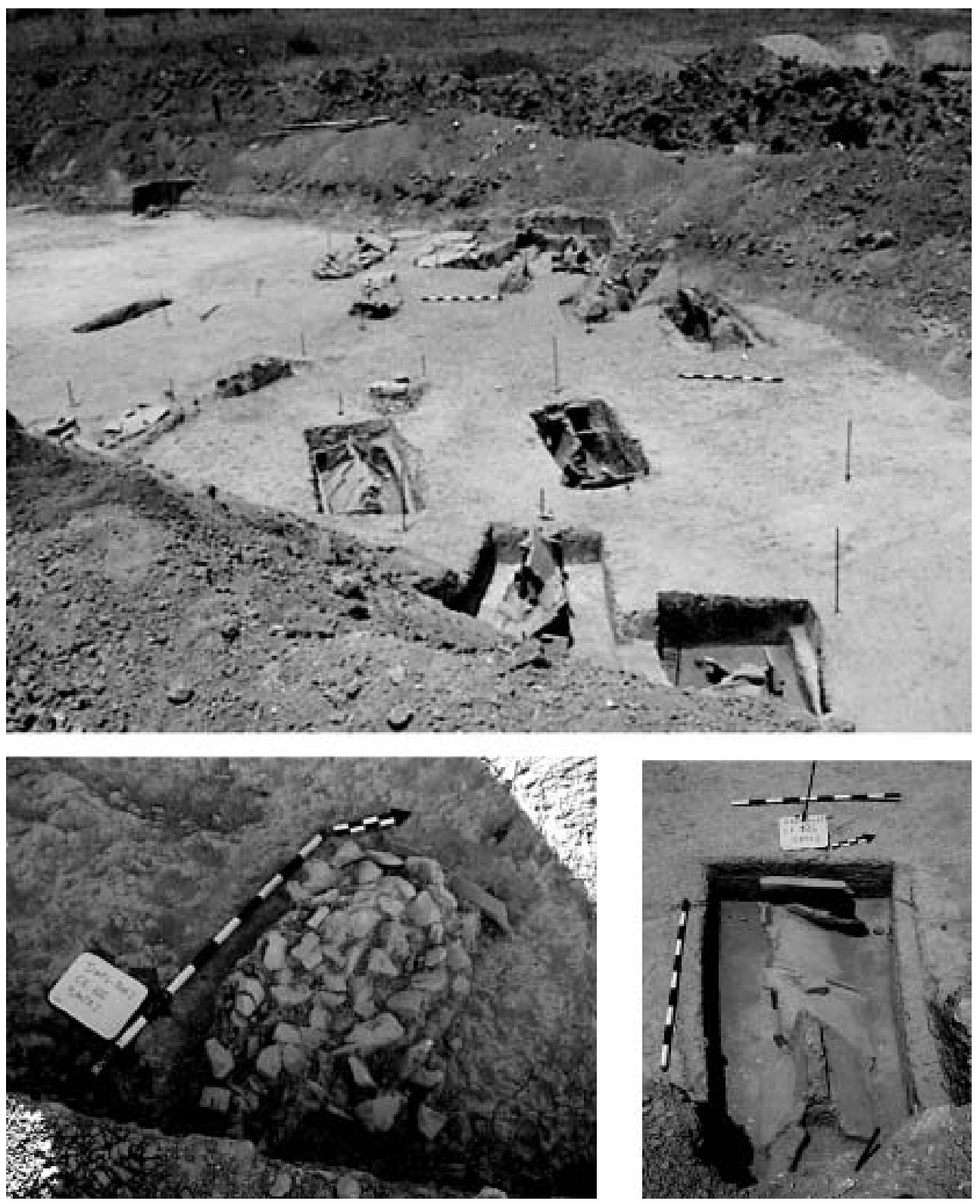

Figura 17. Vistas de la Necrópolis 2.

tipología ritual (Necrópolis 4 y 5), que salvo la situada en la manzana C del RP4. (Rodriguez-Ariza et alii 2005) son también de época visigoda por la tipología de las fosas antropomorfas, y corresponden ya a época islámica emiral temprana (Serrano y Castillo 2000; Pérez y Serrano 1997; Burgos et alii 2001). La ausencia de ajuares dificulta mucho su datación, y dado que el ritual es claramente cristiano, con orientación de la cabecera al oeste, tumbas antropomorfas, cubiertas de losas de caliza, tégulas, etc. sólo podríamos decir que son de tradición romana y de rito cristiano. Sin embargo, la aparición puntual de elementos claramente islámicos, como un felús de 745 en la tumba 15 del Distribuidor Norte (Salvatierra et alii 2001), y la aparición de enterramientos de rito cristiano e islámico en una misma necrópolis, sugieren la pervivencia del cristianismo durante mucho tiempo en el territorio conquistado de Aurgi, coexistiendo los cultos y manteniéndose por tanto necrópolis de aspecto ritual tardorromano hasta este momento medieval. 


\section{DISCUSIÓN}

En nuestro planteamiento defendemos que la Necrópolis 1 del asentamiento Los Robles se crea al margen de otros espacios funerarios que ya venían asumiendo el papel aglutinador del linaje aristocrático y su clientela urbana, que deben vincularse con el propio oppidum de Santa Catalina y el asentamiento indígena posterior a la II Guerra Púnica. La inauguración de la necrópolis de Los Robles tiene que relacionarse necesariamente con un hecho que redefina las relaciones sociales creadas en el marco de la ciudad, y este no es otro que la fundación del municipio latino de Aurgi y su organización municipal. Para explicarlo hemos de entender por qué Los Robles, siendo un sitio muy próximo al municipio, apenas 2 kilómetros, de clara proyección económica y ostentación pública, dada la industria aceitera que controla (hemos de recordar que el auge de la producción de aceite bético se produce a partir de época flavia, desde finales del siglo i y a lo largo de todo el siglo II), no creó un espacio funerario junto a la propia ciudad, donde la función representativa tendría mayor impacto que en el ambiente rústico donde se definió. Esta contradicción debe tenerse en cuenta para nuestro posterior análisis.

Para nosotros la clave está en las circunstancias de la fundación de los municipios flavios de menor entidad urbana. La promoción de Vespasiano aspiraba más a ampliar la base social que apoyaba la nueva dinastía y a redefinir el sistema impositivo (Castro, 1998; Cortijo, 1993) que a ampliar la ciudadanía romana como sistema de integración indígena en el imperio. Por ello no se discriminó asentamientos de escasa relevancia urbana, como el caso de Aurgi (Serrano, 2004a). El derecho latino amparaba unas ciertas condiciones de igualdad ante el Estado de los habitantes libres de los municipios recién promovidos, lo que creaba de golpe una amplia y homogénea base de apoyo popular, con las implicaciones económicas que ello significaba entre las comunidades indígenas. De cualquier forma, estas presentaban diversas situaciones de relación en el marco del complejo sistema aristocrático-clientelar que definía la sociedad indígena en proceso de romanización. No podemos creer que estas condiciones previas desaparecieran sin más, como tampoco que las diferencias sociales privilegiadas, sustentadas en la posesión de los medios de producción, la tierra, no tuviesen su proyección en la ordenación municipal. El evergetismo municipal se basa en el poder económico que la clase de mayor renta podía destinar a su ciudad. Esta cuestión es la que podemos deducir de la epigrafía honorífica de
Aurgi. Pero, de hecho, estas condiciones privilegiadas se pueden seguir en el registro arqueológico. Marcelo Castro (1998) observó cómo los sitios ibéricos habitados en el momento de la municipalización flavia, localizados en turres en la periferia del oppidum de Atalayuelas, cerca de Jaén, siguieron siendo ocupados hasta momentos muy tardíos, siglo $\mathrm{V}$, constituyéndose en grandes villae, que de alguna manera podían constituir grandes propiedades al situarse en espacios interpretados como tierras comunales del oppidum. El reparto de la tierra en las centuriaciones subsiguientes a la municipalización, de las que tenemos evidencias arqueológicas en distintos puntos de la ZAMB, que resultó un proyecto fallido en apenas un siglo, puede haberse resuelto con situaciones similares en Aurgi, es decir, con la apropiación de grandes lotes de tierras por compra o apropiación.

Durante los años ochenta y noventa del siglo xx se realizaron numerosos trabajos de prospección superficial a lo largo de la Campiña de Jaén al amparo del entonces proyecto de investigación sistemática «El poblamiento ibérico en las campiñas de Jaén», dirigido por Arturo Ruiz y Manuel Molinos (Montilla 1987; Lagunas et alii 1991; Castro 1998; Serrano et alii 1990). A estos hay que añadir otros trabajos sistemáticos como los llevados a cabo por Ponsich (Ponsich, 1987) a lo largo del Guadalquivir a mediados de los ochenta. Todos aquellos trabajos sistemáticos revelaron un poblamiento inédito de época romana que tenía su origen, en la mayor parte de las zonas estudiadas, en la municipalización flavia. Pero lo que destaca de esa ocupación rural campesina es su interrupción brusca en un periodo de tiempo muy corto a lo largo de la segunda mitad del siglo II. El hecho, contrastado tanto por prospección de superficie como por excavaciones de urgencia y sistemáticas en hábitat rural y algunos núcleos municipales (Castro 1989; Choclán y Castro 1988; Hornos et alii 1987; Choclán 1990; Serrano 2004; Castro 1998; Ruiz et alii 1992), suponía la desaparición de más del 70\% del hábitat campesino. El principal fósil guía de esta secuencia histórico-arqueológica no era otro que el de la terra sigillata hispánica de Andújar (Isturgi), cuya difusión local en la Campiña de Jaén no se produce hasta época flavia y siglo II, cuando la demanda del producto se produce allí, mientras que antes de ese momento su distribución se producía mayoritariamente en el Guadalquivir Medio y Bajo. La interrupción de la producción de los alfares isturgitanos se ha argumentado desde el agotamiento de las canteras de arcilla hasta la competencia de los productos africanos (Roca 1998). Sin embargo, la distribución de sigillatas claras A y A/C, verdaderamente escasa en prospección 


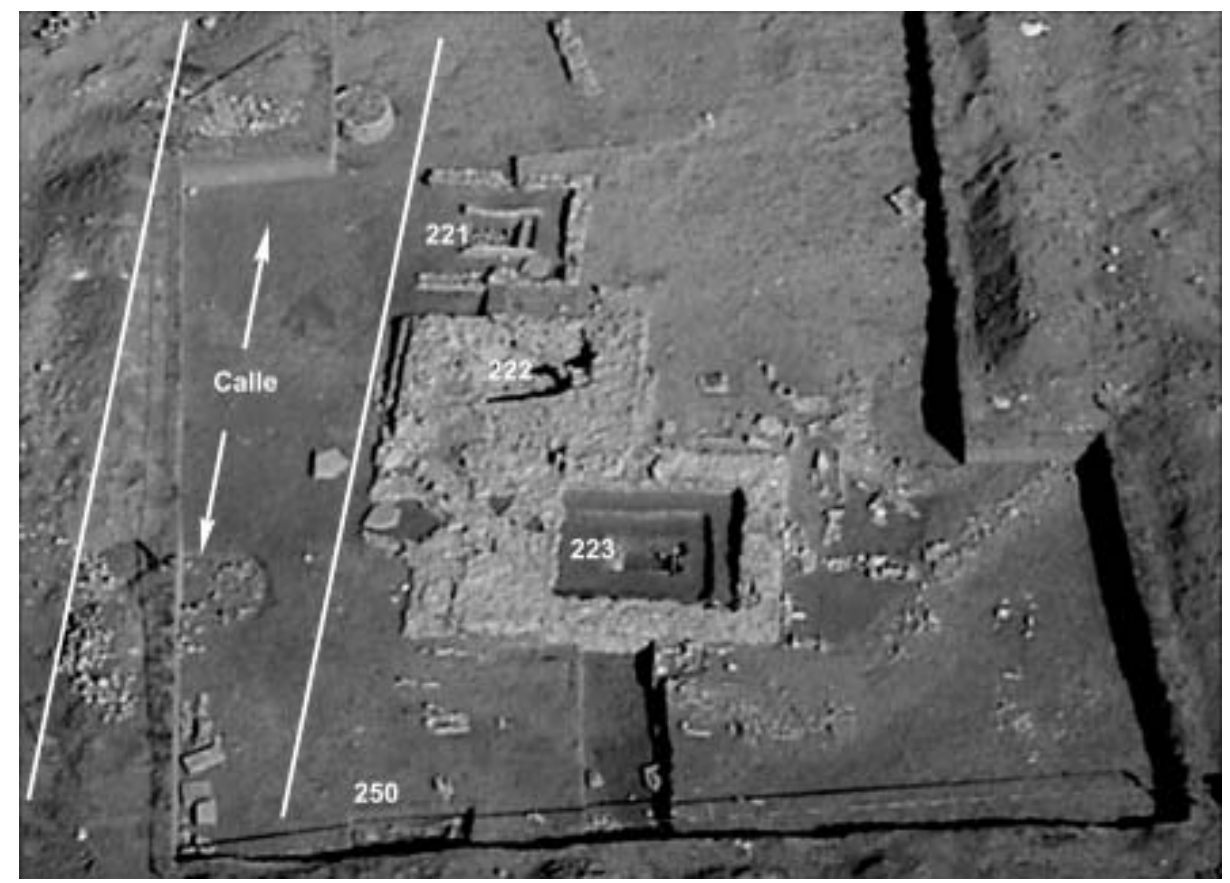

Figura 18. Vista aérea de la Necrópolis 1.

y en las excavaciones, no apoya esta hipótesis. Para nosotros, el cese de la ingente producción de los alfares (de sigillata y otros de cerámica común) sólo puede explicarse desde la óptica de la crisis del mercado, es decir, la drástica reducción de la demanda de productos de cierto lujo como la vajilla de mesa. Y ello producido no por un cambio de gusto sino porque la crisis del sistema municipal estalla en su misma base, el campesinado que se benefició del reparto de la tierra del antiguo oppidum. En este sentido hemos de recordar que algunos cálculos realizados en relación al tamaño de las parcelas asignadas proponen superficies bastante pequeñas, casi en el límite de la subsistencia (Choclán y Castro 1988). La ausencia de los materiales característicos de la segunda mitad del siglo in y del siglo III sólo puede explicarse en la ausencia de demanda a gran escala, lo que en contraste con el periodo flavio-antonino evidencia la invisibilidad del campesinado libre, aunque reconocemos la reactivación del mercado a partir del siglo iv.

Hemos defendido que las causas que explican la reducción de la producción de aceite en la almazara de Cuétara en época flavia, a unos 600 metros al este de Los Robles, es precisamente consecuencia de la asignación de tierras al pequeño campesinado, de modo que la producción se diversificó en las pequeñas y medianas propiedades (Serrano 2004b). Pero si en el caso de esa almazara es evidente no sólo el momento de fundación municipal, sino también la crisis del siglo II que provoca su abandono, en el sitio de Los Robles la situación es muy diferente. Podemos apreciar la reforma en profundidad de las edificaciones a finales del siglo i d.n.e. (López et alii 2007), pero la continuidad de la ocupación con el progresivo enriquecimiento de las edificaciones hasta época visigoda sugiere una posición privilegiada que le permitiría asumir las consecuencias de la fundación de Aurgi y después la crisis del siglo II desde una posición ventajosa.

La necrópolis es, entendemos, un reflejo de ello. Una necrópolis privada, tan cerca pero a la vez tan lejos de la ciudad, diseñada para la representación pública de los antepasados familiares, sólo puede explicarse por el limitado valor que los propietarios dan al hecho mismo de la función representativa del municipio, pero sobre todo confiere un valor especial a la propiedad, la propia familia, sus antepasados y a las relaciones de clientela que mantiene con parte de la población de Aurgi. No pretendemos decir que cualquier necrópolis documentada en sitios rurales tenga necesariamente que responder a funciones representativas, pero, en este caso, las circunstancias del sitio que estudiamos, sus precedentes y la propia historia del municipio así lo sugieren.

El poder puede tener muchas formas de representación, y en el caso del mundo romano imperial se 
expresa en unas complejas relaciones a caballo entre dos mundos cultural y socialmente diferentes: el mundo indígena en proceso de aculturación y la cultura romana, adaptada a las particularidades indígenas; y esto es así para cualquier rincón conquistado. En este diálogo, tradicionalmente se ha querido ver la voluntad inequívoca del ibero por convertirse en romano. Estrabón (3.2.15) ya mostraba su admiración por ese fenómeno, pero esa expresión de júbilo, y la defensa que la historiografía tradicional ha hecho de la aculturación como un proceso unilineal sin vuelta atrás, puede ser matizado desde la arqueología en aspectos referidos a la resistencia indígena a los cambios en determinados aspectos sociales (Bendala, 2002), entre los que los ideológicos y simbólicos debieron ser muy importantes.

Es evidente que el primer elemento que explica el fuerte contenido indígena en las comunidades conquistadas, al menos durante la republica y primera edad imperial, es precisamente la tardía romanización de la sociedad indígena a través de mecanismos legales de gran calado, es decir, que frente a las concesiones de derechos de forma virital o limitada a comunidades concretas, que son tan frecuentes en ese periodo, la romanización generalizada a todos los niveles sólo se produjo a partir de época flavia con el edicto de latinidad a las comunidades de Vespasiano. De esta forma, la sociedad provincial mantendrá en su seno unas relaciones de corte tradicional, tanto en la organización de las comunidades como en las relaciones entre individuos, y más allá, con la propia Roma. Quizá la mejor prueba de ello sea que, salvo el caso de la Colonia Augusta Gemella Tucci (Martos), en la campiña de Jaén no existe poblamiento rural de corte itálico hasta finales del siglo I d.n.e., habitando todo el campesinado en el oppidum, como había ocurrido en las fases plenas iberas, lo que obliga a pensar en la propiedad de la tierra y medios de producción como en un factor controlado por la aristocracia indígena (Ruiz et alii 1992). Los casos que conocemos de ocupación rural ibérica, como el propio caso de Marroquíes Bajos (Serrano 2004a), sólo pueden explicarse, en ausencia de un marco legal romano que regule la propiedad privada de la tierra, por la existencia de una estructura aglutinante, esto es, un territorio aristocrático. Pero las pervivencias de las tradiciones indígenas se extienden hasta el extremo de que es frecuente la pervivencia de nombres indígenas en los núcleos urbanos en los que existe epigrafía anterior a época flavia, como por ejemplo en la vecina $U r$ gavo (Arjona) (CIL II, 2114) y Mentesa (La Guardia) (González y Mangas 1991: 282).
La reafirmación del valor de la tierra y de su vinculación al linaje, la familia si se prefiere, queda así sellado mediante la creación del espacio funerario, pero expuesto al culto público de los antepasados, más allá de las relaciones de servidumbre que se plantean en la casa. El concepto de pagus y las relaciones particulares que implicaba entre la tierra, la aristocracia y el campesinado, se renuevan ahora mediante fórmulas adaptadas a la nueva realidad política del imperio. Las clientelas tradicionales ibéricas mantendrán vinculaciones con las familias aristocráticas, que podrían explicar el grado de concentración de la propiedad y la usurpación de las tierras de la comunidad una vez que empiece la crisis en la segunda mitad del siglo II d.n.e. (Castro 1998). La arqueología advierte de que los modelos de reparto de tierras mediante centuriaciones fueron, en el entorno de Aurgi, un breve episodio que no perduró mas allá de la crisis, poco mas de un siglo, entre Vespasiano y Cómodo, en el mejor de los casos. Al mismo tiempo, la reafirmación de los lazos con la tierra en el periodo de eclosión municipal tiene que ver con la realidad económica del imperio más que con la cuestión política. En la gran mayoría de los municipios creados en época flavia, el cursus honorum sería una carrera política de interés limitado; en estos pequeños núcleos urbanos la posibilidad de acceder a la máxima dignidad senatorial sería remota (Le Roux 2006), por lo que, en realidad, el horizonte político no sería más que un medio de consolidación de derechos tradicionales. El poder procedía de la tierra, y en el caso de Los Robles, el control de la industria del aceite en el periodo de máximo auge de su exportación sería por sí solo un elemento de prestigio, y de poder, suficiente. Hemos de recordar que la mayoría de los núcleos urbanos promovidos a municipio en época flavia son muy pequeños y de escasa población. Un ejemplo significativo por su proximidad es la escala que se propone para Puente Tablas en el siglo Iv, un oppidum de unas 5,5 hectáreas amuralladas, un tamaño medio para la campiña de Jaén. Las prospecciones geofísicas realizadas allí apuntaban a la definición de unas 165 casas y una población de unas 742 personas (Ruiz y Molinos 2007). Si al municipio de Aurgi le calculamos entre 10 y 12 hectáreas acotadas por muralla (Serrano 2004a), podríamos pensar en una población de unas 1.500 personas, si todas vivieran en la ciudad y esta estuviera densamente urbanizada. Con esta población, el control político del municipio y las clientelas sería realmente fácil para pocas familias.

Por otro lado, en lo que se refiere a los aspectos rituales de la ordenación del espacio, la fundación de 
la necrópolis con una tumba de incineración, la que ocupa mayor espacio y la que presenta más rica decoración, la que rige durante poco más de un siglo el espacio funerario, tiene un significado más que simbólico, cuya caracterización no es fácil. El rito de la incineración responde a la tradición romana desde finales del siglo $v$ a.n.e. y hasta la segunda mitad del i d.n.e. perdurando incluso hasta el siglo II, pero también forma parte de la tradición ibérica. Es difícil establecer hasta qué punto la tumba 223 recoge una tradición u otra. La observación del ritual de la incineración parece, a primera vista, netamente romano, con elementos que entran directamente en la cultura itálica, como el uso del lecho funerario durante la cremación y la propia técnica empleada en la edificación, una estructura en forma de altar elevado, accesible con peldaños (que no son ajenos a la tradición ibera, como es sabido) y elaborado a base de hormigón (opus caementicium) y ricamente decorada con mármoles polícromos, siendo la marmorización de la edilicia un elemento de romanidad ya sugerido en otros municipios (Vaquerizo 2001). La ubicación del ustrinum dentro de la propia estructura es un hecho también frecuente en las necrópolis de incineración romanas, e incluso la excavación de la cámara dentro de él. Sin embargo, en conjunto casi todos esos elementos forman parte de la tradición centenaria indígena, en necrópolis monumentalizadas y organizadas aristocráticamente. Las tumbas principescas de Castulo o Baza representan formas endocéntricas de organización espacial, que en Los Robles adoptan formas urbanas expresadas en la calle que recorre y articula la necrópolis. El diseño de la tumba se realiza para delimitar una porción de tierra virgen, y que a pesar de la profundidad que alcanzan los muros perimetrales que delimitan el edificio, no existe tratamiento en su base, quedando la cámara encajada en la tierra natural. En nuestra opinión, se trata de un ritual deliberado que pretende vincular al difunto con la tierra que lo acoge. Desgraciadamente, el expolio sufrido por la tumba en época imperial nos ha privado de los datos fundamentales del ajuar y ofrendas allí depositados. Los únicos elementos que nos han llegado son un anillo de oro deformado por el fuego y un disco de plomo. La ausencia de cerámica o vidrio fragmentado, que serían parte natural del expolio, sugiere que se extrajeron uno o varios recipientes metálicos o pétreos completos, ya sea una urna de plomo u otro metal, ya sea una caja cineraria de piedra similar a las que conocemos del entorno (Madrigal 1994).

Pero más allá del contenido y forma de la tumba, destaca al hecho de que la inauguración de la necrópolis se hace sobre el rito tradicional, y que a partir de ese momento, todas las tumbas que se construyen responden al nuevo rito oriental de la inhumación, una forma de enterramiento completamente ajeno a la tradición indígena, pero cuya extensión coincide con la consolidación del sistema municipal y de la nueva dinastía flavia. La tumba 223 cierra un ciclo de vida de una sociedad tradicional enfrentada a una renovación política y social muy rápida, que presenta contradicciones evidentes en las relaciones municipales, abierta a nuevas expectativas, pero conservadora de las tradicionales identidades iberas. Los aspectos ceremoniales representados en los espacios residenciales de la fase flavia del complejo Los Robles, donde destacan las esculturas dispuestas alrededor del impluvium de la fuente monumental (Castro 2009), reafirman los fuertes lazos que unen la aristocracia indígena con la nueva dinastía, incluso más allá de los que se habían establecido en el periodo julio-claudio, cuando se construyen las primeras almazaras de Aurgi. Por primera vez podemos asistir a representaciones religiosas e ideológicas de la nueva cultura. Ahora bien, la ideología en el complejo Los Robles se representa de forma parcialmente pública, porque el público al que va dirigida se circunscribe a la propiedad. Pero al mismo tiempo no está limitada, en toda la extensión de la palabra, como demuestran los datos arqueológicos del área excavada en Marroquíes Bajos, siendo una propiedad excepcionalmente grande y compleja. Con toda seguridad el poder de la clase aristocrática romanizada se manifiesta en el foro municipal de Aurgi, donde, como conocemos, se expondrán las imágenes del poder en los espacios públicos, con vocación de trascender a toda la comunidad (Serrano 2004a).

La dualidad de espacios de representación es reflejo, en nuestra opinión, de la concepción ideológica del poder indígena. Se ha cedido parte de él al municipio, en la ilusión flavia de un mundo municipal ordenado y ajustado a la complejidad de Roma en ese momento, pero se reserva el espacio pseudo privado del complejo Los Robles, donde reside el verdadero poder, en el centro mismo de la tierra.

La necrópolis del complejo inaugura no sólo una nueva forma de ocultación de los difuntos, la inhumación, sino que verdaderamente constituye la primera manifestación funeraria fuera de los espacios consignados a tal fin en la Aurgi republicana y de primera edad imperial, estén donde estén. En el millón y medio de metros cuadrados investigados hasta ahora en Marroquíes Bajos no se ha documentado ninguna tumba ibérica de ningún periodo. Y ello es así porque el ordenamiento aristocrático limitaría su uso a espacios 
acordados en las proximidades del asentamiento. $\mathrm{Ni}$ siquiera durante el desarrollo inicial de la producción oleícola en época augustea y julio-claudia podemos reconocer espacios funerarios, porque, a pesar de la importancia de esa industria, no existe hábitat permanente antes del ordenamiento municipal, hecho confirmado por las intervención en la almazara de Cuétara en 1999 (Serrano 2004b). Aunque esto quizá debamos matizarlo en relación a Los Robles, donde se documenta una fase de la primera edad imperial, todavía por definir. No podemos descartar que pueda localizarse una necrópolis de incineración en el propio cerro Los Robles, pero en ese caso habría que ponerla en relación con un núcleo habitado desde por lo menos el Bronce Final-Ibérico Antiguo, que en su papel de control del territorio, habría generado una necrópolis de alcance limitado.

La fundación de la necrópolis de Los Robles a partir de época flavia, con un monumento funerario desarrollado alrededor del rito de la incineración, pretende enlazar con la tradición, y más aún tratándose de un personaje de peso en la escena municipal de Aurgi, como sugieren las características del ritual fúnebre. Algunos elementos aparecidos en el ustrinum, como las tachuelas de caligae, podrían interpretarse como parte de la indumentaria militar, pero la ausencia de otros elementos relacionados, como restos de coraza, casco, armamento, etc., parece contradecirlo, aunque no lo descarta. Creemos que este calzado de tipo militar debe interpretarse como las sandalias de un personaje revestido de autoridad, próximo al poder o imbuido de él, de ahí el lecho funerario y la propia estructura y apariencia externa de la tumba, pero enraizado en la tradición indígena y en los valores de esta, y por eso la cámara funeraria excavada en la tierra virgen y sin apenas tratamiento decorativo interior. Hemos de recordar que durante este periodo del siglo I d.n.e. ya se construían tumbas de gran lujo de estilo romano, y para ello basta recordar las elaboradas estructuras de las necrópolis de Los Chorrillos en Iliturgi (Cerro Máquiz, Mengíbar) (Archivo de la Delegación de Cultura de Jaén), la de Carmona (Bendala 2002) o los monumentos funerarios de la Puerta de Gallegos, en Córdoba (Vaquerizo 2001).

El desarrollo inmediato de la necrópolis de inhumación, coincidiendo con la fundación del municipio, establece una coincidencia que parece tener más trascendencia de lo que aparentemente expresa. Sabemos que desde finales del siglo i d.n.e. y sobre todo desde comienzos del siglo II se introduce progresivamente la inhumación en la península ibérica, y de forma generalizada desde mediados del siglo II. Esta moda, común en Roma y oriente del Imperio, se manifiesta, por el momento, como el rito predominante asociado al municipio de Aurgi. Con la deductio del municipio se inauguran nuevos espacios funerarios en las vías de acceso a la ciudad, que hasta donde sabemos, no enlazan con espacios funerarios anteriores. Así, por ejemplo, en la cantera que se explotó para extraer bloques de caliza para la construcción de la muralla romana flavia, una vez acabada esta a finales del siglo I d.n.e., se aprovecha el espacio como necrópolis urbana. Esta necrópolis, sugerida desde antiguo por la aparición de epigrafía (Gonzalez y Mangas 1991, no 41) y sólo recientemente documentada arqueológicamente en un solar (Gonzalez et alii 2006), presenta rituales funerarios tanto de inhumación como de incineración. La continuidad de la incineración, aunque aparentemente en menor proporción que la inhumación ${ }^{10}$, con cronologías entre el siglo II y III d.n.e., demuestra que no se ha producido una ruptura inmediata con las tradiciones. Sin embargo, la modernidad del nuevo rito de la inhumación parece asociarse a la nueva clase del campesinado libre integrado en el orden municipal, una clase de pequeños propietarios beneficiados del orden generado por los flavios. Y decimos que ello sería circunstancial si no fuera porque desconocemos el rito de la incineración asociado a la expresión económica última del sistema municipal, la casa campesina rural, al menos en el Alto Guadalquivir. Si el fenómeno de cambio de ritual fuese paulatino, deberíamos localizar espacios funerarios asociados al campesinado rural en los que la transición entre ambos ritos estuviera de manifiesto a lo largo de un periodo entre el último cuarto del siglo i y por lo menos el siglo III.

Es evidente que los procesos de conquista y colonización se definen por la complejidad de las relaciones que se generan, relaciones de conflicto multidireccional porque implican no solo las que se establecen entre indígenas y conquistadores, sino que se refieren a todo el complejísimo entramado que define tanto a los indígenas como a los propios conquistadores. Las generalizaciones en estos casos son siempre simplificaciones que pueden llegar a convertirse en falsificaciones del hecho histórico. Un ibero completamente romanizado difícilmente llegaría a convertirse en un verdadero romano. Podríamos prácticamente concluir, parafraseando a Homi Bhabha (1994), que romanizarse fue una forma de no ser romano ${ }^{11}$.

${ }^{10}$ En la intervención arqueológica se documentaron seis tumbas, de las que sólo una era de incineración, correspondiente al momento más antiguo.

${ }^{11}$ «Anglinizarse es una forma enfática de no ser inglés». 


\section{BIBLIOGRAFÍA}

Bhabha, H. K. 1994 (2002): The location of culture. London - New York.

Bendala, M. 2002: «Perduraciones y romanización en Hispania a la luz de la arqueología funeraria: notas para una discusión». Archivo Español de Arqueología 75, nos. 185-186, Instituto de Historia. Consejo Superior de Investigaciones Científicas. Madrid.

Bendala, M. 2003: «De Iberia in Hispaniam: el fenómeno urbano». L. Abad (ed.) (2003): De Iberia in Hispania. La adaptación de las sociedades ibéricas a los modelos romanos. Alicante.

Blázquez, J. M. 1975: Cástulo I. Acta Arqueológica Hispánica 8. Madrid.

Blázquez, J. M. 1979: Cástulo II. Excavaciones Arqueológicas en España 105. Madrid.

Blázquez, J. M. y M. P. García Gelabert 1987: «La necrópolis del Estacar de Robarinas, Cástulo: tipología de los enterramientos». Archivo de Prehistoria Levantina XVII, 177-193.

Blázquez, J. M. y Molina, F. 1975: «Necrópolis de la Puerta Norte de Cástulo». En J. M. Blázquez, Castulo I. Acta Arqueológica Hispánica 8, 237-304

Blázquez, J. M. y J. Valiente 1981: Cástulo III. Excavaciones Arqueológicas en España 117. Madrid.

Burgos, A.; Lizcano, R.; Pérez, C. 2001: «Actuación arqueológica realizada en el bloque A de la UA 25 de Jaén». AAA 1998. Tomo III. Actividades de Urgencia. Volumen 1. Sevilla, 414-421.

Burnett, A., A. Amandry, y P.P. Ripolles 1992: Roman Provincial Coinage. Vol. I : Hispania. London-Paris.

Canto, A. 1979: «Necrópolis de la Puerta Norte. Campañas de 1971 y 1972». En Blazquez, J.M. (1979): Cástulo II. Excavaciones Arqueológicas en España 105. Madrid, 9-87.

Canto, A. y Urruela, J. J. 1979: «Necrópolis del «Cerrillo de los Gordos» (Campaña de 1971)». En Blázquez, J.M. 1979: Cástulo II. Excavaciones Arqueológicas en España 105. Madrid, 321-346.

Castro López, M. 2009: «Cortijo de Los Robles. Excavación B. Julio-Agosto 2006». En Una imagen y mil piedras, la arqueología de Jaén a través de la fotografía. Diputación de Jaén, 102-103.

Castro López, M.; López, J.; Zafra, N.; Crespo, J. M.; Cloclán, C. 1990: «Prospección con sondeo estratigráfico en el yacimiento de Atalayuelas, Fuerte del Rey (Jaén)». AAA, II 1987, 207 215. Sevilla.

Castro López, M. 1989: «De César a Teodosio (49 a.C - 395 d.C) «. En Historia de Jaén. Tomo II. Diputación de Jaén. Jaén, 423441
Castro López, M. 1998: La campiña de Jaén en los siglos I-II. La construcción de un paisaje agrario. Tesis doctoral de la Universidad de Jaén. Inédita.

Chic, G. 1994: «La proyección económica de la Bética en el Imperio Romano (época altoimperial)». En Actas del II Congreso de Historia de Andalucía. Córdoba. 1991. Ed. Consejería de Cultura, Medio ambiente de la Junta de Andalucía y Cajasur, 173-200.

Choclán Sabina, C. 1984: La cerámica iberorromana producida en el alfar de Los Villares de Andújar (Jaén). Campañas de 1981-1982. Universidad de Granada. Memoria de Licenciatura inédita.

Choclán Sabina, C. 1990: «Excavación de urgencia en el cerro del Espino (Torredelcampo, Jaén)». Anuario Arqueológico de Andalucía III. Sevilla. Páginas 157-163.

Choclán, C.; Castro, M. 1988: «La Campiña de Alto Guadalquivir en los siglos I-II d.C. Asentamientos, estructura agraria y mercado». Arqueología Espacial 12, 205-221.

Cortijo Cerezo, M. L. 1993: La administración territorial de la Bética romana. Colección Plaza Mayor n⿳ 12. Obra Cultural de la Caja Provincial de Ahorros de Córdoba. Córdoba.

Crespo, J. M., Castro, M., López, J. y Choclan, C. 1987: «Prospección con sondeo estratigráfico en la finca Gil de Olid, Puente del Obispo (Jaén)». Anuario Arqueológico de Andalucía, II, 1986. Sevilla.

García-Bellido, M. P. 1982: Las monedas de Cástulo con escritura indígena. Historia numismática de una ciudad minera. Barcelona.

García-Bellido, M. P. y Blázquez Cerrato, C. 2001: Diccionario de cecas y pueblos hispánicos. CSIC. Madrid.

Gámez, J. T.; Moya, S. R. 2001: «Actuación Arqueológica de Urgencia en el solar n⿳011 de la calle Olid de Jaén». Anuario Arqueológico de Andalucía de 1998. I.Actividades de Urgencia. Sevilla, 394-401.

González, A.; Nicas, J.; Cruz, A. 2006: Intervención Arqueológica Preventiva en la Calle Millán de Priego $N^{o}$ 30. Jaén. Archivo de la Delegación de Cultura de la Junta de Andalucía en Jaén.

González Román, C. 1999: «El trabajo en la agricultura de la Hispania romana». En F. Rodríguez Neila, C. González Román, J. Mangas y A. Orejas (eds.), El trabajo en la Hispania romana. Madrid, 119-206.

González Román, C.; Mangas Manjarrés, J. 1991: Jaén. Tomo I. Corpus de Inscripciones latinas de Andalucía, Vol. III. Consejería de Cultura y Medio Ambiente de la Junta de Andalucía. Dirección General de Bienes Culturales. Sevilla. 
González Villaescusa, R. 2001: El mundo funerario romano en el País Valenciano. Casa de VelázquezInstituto Alicantino de Cultura «Juan Gil-Albert». Madrid-Alicante.

Hornos Mata, F.; Castro López, M.; Lagunas Navidad, M. A.; Montilla Pérez, S. 1987: «Actuación arqueológica de urgencia en Cabeza Baja de Encina Hermosa (Castillo de Locubín, Jaén)». Anuario Arqueológico de Andalucía 1986. Tomo III. Actividades de Urgencia. Sevilla, 203-209.

Hornos Mata, F., Zafra De La Torre, N. y Castro López, M. 2000: «Perspectivas, itinerarios e intersecciones: experiencias y propuestas de apropiación cultural de Marroquíes Bajos (Jaén)». Trabajos de Prehistoria 57, 105-118.

Jiménez Díez, A. 2008: Imagines Hibridae. Una aproximación postcolonialista al estudio de las necrópolis de la Bética. Anejos de Archivo Español de Arqueología XLIII. Madrid.

Keay, S. y Terrenato, N. (edit) 2001: Italy and the West. Comparative issues in Romanization. Oxford.

Le Roux, P. 2006: Romanos en España. Ciudades y política en las provincias (siglo II a.C. - siglo III d.C.). Ediciones Bellaterra-Arqueología. Barcelona.

Lagunas, M. A.; Risquez, C.; Serrano, J. L.; 1991: «Prospección arqueológica superficial en el curso bajo del río Jandulilla». AAA II. Sevilla, 110115.

López, A. E. Teixidor y M. Fuertes 2007: Excavación arqueológica preventiva de Colector en Distribuidor Norte (ZAMB, Jaén). Informe preliminar. Archivo de la Delegación de Cultura en Jaén.

López, A.; Baena Del Alcázar, L. 2007: «Un retrato femenino flavio en la villa romana del Cortijo de Los Robles (Jaén)». Revista mus-A. Revista de los Museos de Andalucía. Julio 2007. Consejería de Cultura de la Junta de Andalucía. Dirección General de Museos, 161-184.

Madrigal Belinchón, A. 1994: «Cajas funerarias ibéricas de piedra en Andalucía oriental». En Actas del II Congreso de Historia de Andalucía. Córdoba. 1991. Ed. Consejería de Cultura, Medio ambiente de la Junta de Andalucía y Cajasur, 113120.

Molinos, M. y Fernández, R. 2006: Intervención arqueológica preventiva en la c/ Alférez Manuel Casado 4 (Porcuna, Jaén). Archivo de la Delegación de Cultura en Jaén.

Montilla Pérez, S. 1990: «Prospección arqueológica superficial en el término municipal de Alcaudete (Jaén): análisis y conclusiones en torno a un mues- treo probabilístico planteado entre las cuencas fluviales de los ríos Víboras y San Juan». AAA 1987. Tomo II, Sevilla, 132-138.

Montilla, S., Rísquez, C., Serrano, J. L. y Coba, B. 1989: «Análisis de una frontera durante el horizonte ibérico en la depresión Priego-Alcaudete». Arqueología Espacial 13,137-149.

Mattingly, E., Sydenham, E. A., Sutherland, C. V. y Carson, R. A. G. 1923-1951: Roman Imperial Coinage, $\mathrm{X}$ vol. London.

Ortiz, A.; Serrano, J. L. 2008: Intervención arqueológica preventiva en la Parcela RC8 de la $3^{a}$ Fase de la Urbanización SUNP 1 de Jaén. Archivo de la Delegación de Cultura de Jaén.

Palol, P. 1972. «Una tumba romana de Toledo y los frenos de caballo hispanorromanos del Bajo Imperio». Pyrenae 8, 133-146.

Pérez Martínez, M. C. 1997: Intervención Arqueológica en la Zona Arqueológica de Marroquíes Bajos: Galerías Visitable en la Cabecera del Bulevar. Obras de Urbanización del RP4. Archivo de la Delegación Provincial de Cultura en Jaén.

Pérez Martínez, M. C. y Serrano Peña, J. L. 1997: Intervención Arqueológica en la Zona Arqueológica de Marroquíes Bajos: calle D-D'. Urbanización del RP4. Archivo de la Delegación Provincial de Cultura en Jaén.

Ponsich, M. 1987: Implantation rurale antique sur le bas-Guadalquivir. Tomo III. Publications de la Casa de Velásquez, serie Archeologie. Madrid.

Portero, V.; Serrano, J. L.; Cano, J. 2007: Intervención arqueológica preventiva en la UE 17 de Jaén. Centro Comercial El Corte Inglés II. Archivo de la Delegación de Cultura de Jaén.

Roca Roumens, M. 1998: «Reflexiones acerca de las estructuras de producción de sigillata en el centro de Andújar». En Terra Sigillata Hispánica. Estado actual de la investigación. Universidad de Jaén, 105-122.

Ruiz, A. 1978: «Los pueblos íberos del Alto Guadalquivir. Análisis de un proceso de transición». Cuadernos de Prehistoria de la Universidad de Granada 3. Granada, 255-284.

Ruiz, A., Castro, M.; Choclán, C. 1992: «Aurgi-Tucci: la formación de la ciudad romana en la Campiña Alta de Jaén». En Dialoghi di archaelogia: conquista romana y modos de intervención en la organización urbana y territorial. Elche-Roma.

Ruiz Rodríguez, A. 2009: «Del espacio urbano a la ciudad en la sociedad ibérica». En P. Mateos, S. Celestino, A. Pizzo, T. Tortosa (eds.) Santuarios, oppida y ciudades: arquitectura sacra en el origen y desarrollo urbano del mediterráneo occi- 
dental. Anejos de Archivo Español de Arqueología XLV. Mérida, 153-174.

Ruiz, A. y M. Molinos 1993: Los Iberos. Análisis arqueológico de un proceso histórico. Ed. Crítica. Barcelona.

Ruiz, A.; M. Molinos 2007: Iberos en Jaén. Universidad de Jaén.

Ruiz, A., J. L. Serrano, M. Molinos; O. Rodríguez 2007: «La tierra y los iberos del Alto Guadalquivir». En A. Rodríguez e I. Pavón (ed.): Arqueología de la tierra. Paisajes rurales de la Protohistoria peninsular. VI cursos de verano internacionales de la Universidad de Extremadura. Universidad de Extremadura, 225-245.

Ruiz Rodríguez, A., N. Zafra De La Torre, F. Hornos Mata ; M. Castro López, M. 1999: «El seguimiento de la intervención arqueológica: El caso de Marroquíes Bajos en Jaén». Actas del XXV Congreso Nacional de Arqueología. Valencia, 407419.

Sáez Fernández, P. 1991: «Consideraciones sobre el cultivo del olivo en la Bética hispano-romana. Aspectos económicos y sociales». En C. González Román (ed.), La Bética en su problemática histórica, 277-298.

Salvatierra Cuenca, V., J. L. Serrano Peña; J. Cano Carrillo 2001: «Jaén islámico. La moneda en la interpretación de las primeras fases de la ciudad». IV Jarique de Numismática Andalusí. Jaén.

Serrano, J. L.; Coba, B.; Risquez, C.; Montilla, S. 1990: «Prospección arqueológica superficial en el término municipal de Marmolejo (Jaén)». Anuario Arqueológico de Andalucía 1988. Tomo III. Actividades de Urgencia. Sevilla, 164-166.

Serrano Peña, J. L. 1997: «Un complejo califal en Marroquíes Bajos, Jaén». Arqueología y Territorio Medieval 4, 59-79.

Serrano, J. L.; J. Cano 1999: Intervención arqueológica de urgencia en la Zona Arqueológica de Marroquíes Bajos. Distribuidor Norte. Archivo de la delegación de Cultura de Jaén.

Serrano Peña, J. L. 2004a: Aurgi, estudio del municipio romano desde la arqueología urbana de Jaén, 1985-1995. Universidad de Jaén.

Serrano Peña, J. L. 2004b: «Consideraciones sobre la producción de aceite en el Alto Guadalquivir: el caso de Aurgi (Jaén)». Archivo Español de Arqueología 77, 159-176.

Serrano Peña, J. L.; J. C. Castillo Armenteros 2000: «Las necrópolis medievales de Marroquíes Bajos (Jaén). Avance de las investigaciones arqueológicas». Arqueología y Territorio Medieval 7. Universidad de Jaén, 93-120.
Serrano Peña, J. L.; J. Cano Carrillo; Y. Jiménez Morillas; F. Alcalá Lirio 2001c: Intervención Arqueológica de Urgencia en la red de Saneamiento: Colectores A-1, A-2, A-3. Archivo de la Delegación de Cultura de Jaén.

Serrano Peña, J. L., J. Cano Carrillo, F. Alcalá Lirio; V. Barba Colmenero 2001a: Intervención arqueológica de urgencia en la urbanización SUNP 1 de Jaén. Viales de la $2^{a}$ Fase. Octubre de 2001. Archivo de la Delegación de Cultura en Jaén.

Serrano Peña, J. L.; J. Cano Carrillo 2003: Intervención arqueológica de urgencia. $2^{a}$ fase de la urbanización SUNP 1 de Jaén. Intervención en las Zonas Verdes. Archivo de la Delegación de Cultura en Jaén.

Serrano Peña, J. L.; J. Cano Carrillo 2003: Intervención arqueológica de urgencia en la parcela $R C 3$ de la $2^{a}$ fase de la urbanización SUNP 1 de Jaén. Archivo de la Delegación de Cultura en Jaén.

Serrano, J. L.; J. Cano; A. Ortiz; B. Sánchez; R. Fernández; M. V. Gutiérrez 2005: Intervención arqueológica de urgencia en la urbanización SUNP 1 de Jaén. Viales de la $3^{a}$ Fase. Septiembre de 2005. Archivo de la Delegación de Cultura en Jaén.

Valiente, J. 1999: «Estacar de Luciano. Campañas de 1975 y 1977». En J. M. Blázquez y M. P. García Gelabert, Castulo. Jaén. España. BAR Internacional Series 789, Oxford, 240-253.

Vaquerizo, D. (coord.) 2001: Funus Cordubensium. Costumbres Funerarias en la Córdoba Romana. Seminario de Arqueología. Universidad de Córdoba. Córdoba.

Villaronga Garriga, L., 1994: Corpus Nummum Hispaniae Ante Augusti Aetatem. Madrid.

Zafra De La Torre, N.; Castro López, M.; Hornos Mata, F. 1999: «Una macro-aldea en el origen del modo de vida campesino: Marroquíes Bajos (Jaén) c. 2.500-2.000 cal. A.N.E.». Trabajos de Prehistoria 56, 1, 77-102.

Zafra Sánchez, J. 1997: «Estructuras hidráulicas romanas e islámicas junto al arroyo A de Marroquíes Bajos Jaén». Arqueología y Territorio Medieval 4, 102-113.

Zafra, J.; Serrano, J. L.; Royo, M. A.; Pérez, M. C. 2001: «Prospección arqueológica superficial en el Suelo Urbanizable del término municipal de Jaén». Anuario Arqueológico de Andalucía de 1997. III Actividades de Urgencia. Sevilla, 384-389.

Recibido el 17/05/10 Aceptado el 10/09/10 